\title{
ETHNIC IDENTITY AND SENSE OF SCHOOL BELONGINGNESS: BEHAVIORS AND BELIEFS OF IMMIGRANT HISPANIC STUDENTS AND PARENTS
}

\author{
A thesis \\ Presented to the faculty of \\ California Polytechnic State University \\ San Luis Obispo \\ In Partial Fulfillment \\ of the Requirements for the Degree of \\ Master of Science in Psychology
}

by

Francisco B. Ortiz

March 2009 
(C) 2009

Francisco B. Ortiz

ALL RIGHTS RESERVED 
COMMITTEE MEMBERSHIP

TITLE:

Ethnic Identity and Sense of School Belongingness:

Behaviors and Beliefs of Immigrant Hispanic Students and

Parents
AUTHOR:
Francisco B. Ortiz

DATE SUBMITTED: $\quad$ March 2009

COMMITTEE CHAIR: $\quad$ Lisa I. Sweatt, PhD. Associate Professor

COMMITTEE MEMBER: Kathleen Ryan, PhD. Professor

COMMITTEE MEMBER: Mike Selby, PhD. Professor 


\begin{abstract}
Ethnic Identity and Sense of School Belongingness: Behaviors and Beliefs of Immigrant Hispanic Students and Parents

Francisco B. Ortiz
\end{abstract}

\begin{abstract}
For many decades, the number of minority students, particularly Hispanics, dropping out from school has been noticeable to say the least (Rumberger, 1995). These students have in the past and continue in the present to struggle with the educational system, and it is certain, but not clear, that various factors contribute to Hispanics' poor academic performance and not being able to graduate from High School (Rumbaut \& Cornelius, 1995). Some of these factors are organized in three groups: School-Related; Parental-Related; and Student-Related. Thus, this study is an attempt to understand how immigrant students and parents are currently responding to the challenges of dealing with a foreign educational system. The focus is primarily on how students have to manage a sense of identity while they are trying to incorporate to their schools, and how parents are supporting their children and keeping a dialogue with the schools. It was hypothesized that students' overall ethnic identity would correlate significantly with students' psychological sense of school belonging. Quantitative results showed no statistical correlations between students' ethnic identity and students' sense of school membership. A forced entry multiple regression analysis was conducted to evaluate if any of the subscale scores on the MEIM predicted sense of school belongingness. The predictors were Affirmation and Belonging, Ethnic Identity Achievement, Ethnic Behaviors, and Other-group orientation, while the criterion variable was the total score on the PSSM. The Affirmation and Belonging subscale was the only subscale that was significantly related to psychological sense of school belongingness.
\end{abstract}




\section{ACKNOWLEDGEMENTS}

I would like to express my most cordial and sincere thanks to Dr. Lisa Sweatt, Dr. Kathy Ryan, and Dr. Mike Selby for their time, involvement, support and guidance along the process of completing this project.

To Paty and Paulette: You both are the greatest gifts God has sent me. Thank you for being part of my life.

To my parents, Juan F. Ortiz and Julia Ortiz, I dedicate my whole educational trajectory. GRACIAS POR TODO Y LOS QUIERO!!!

To Juan: I thank God for a brother like you who taught me that there are no boundaries and that one should be grateful for what one has and not unhappy for what we do not possess. May you be in the company of God forever! TE QUIERO MUCHO.

To Maury: Where one goes the other follows. We have had great experiences together and I hope to continue to count with your support and love.

To my sister: I wish you the best in life, and remember that you can count on me for support on whatever endeavor you find yourself involved in. Congratulations to you and Oscar on being parents!!!

"Your Dad is coming, and he is taking us to live in the U.S. ...you will have new opportunities in that country." (My Mom, February 1995) 


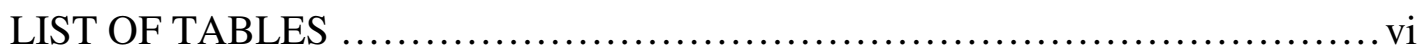

\section{CHAPTER}

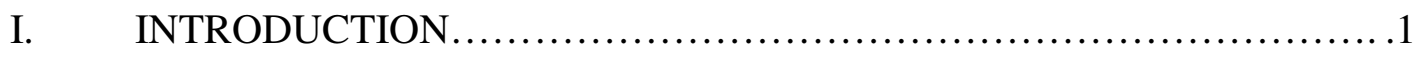

Definition of Terms.............................................

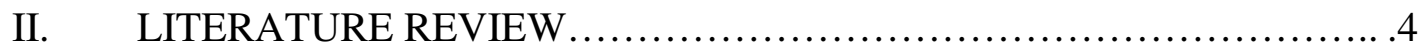

School Related Factors........................................4

Parental Related Factors...................................... 13

Student Related Factors...................................... 16

School Membership...................................... 16

Identity................................................ 18

Motivation...........................................21

Extra Curricular Participation............................ 24

Language............................................. 25

Alternatives.......................................... 26

Statement of the Problem............................................28

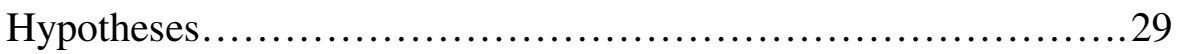

III. METHODOLOGY .................................................. 30

Participants................................................... 30

Materials and Procedures......................................... 31

Instruments....................................................

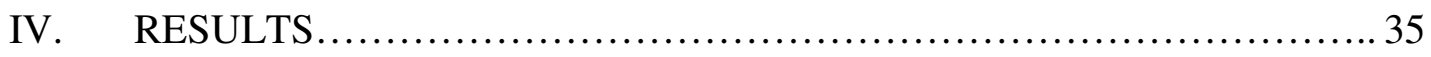

Quantitative Results............................................ 36

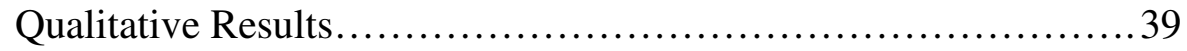

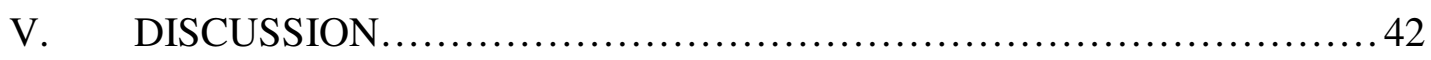

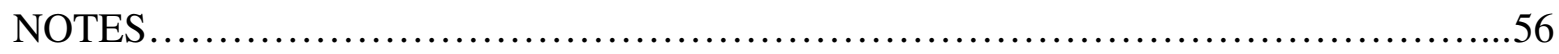

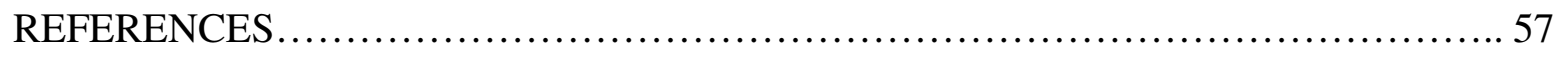

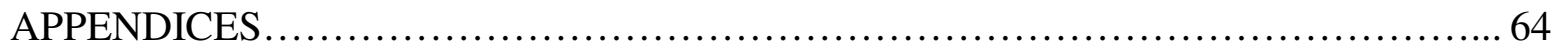

A. The Multigroup Ethnic Identity Measure (English)............................... 64 
B. The Multigroup Ethnic Identity Measure (Spanish) ............................. 68

C. The Psychological Sense of School Membership (English) ........................ 72

D. The Psychological Sense of School Membership (Spanish) ...........................75

E. Parent Questionnaire (English) .......................................... 77

F. Parent Questionnaire (Spanish) ........................................... 79

G. Youth Consent Form (English) .............................................. 81

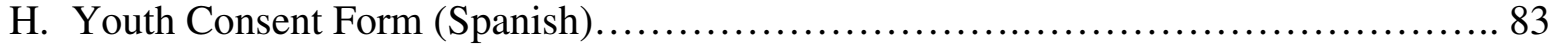

I. Parent Consent Form (English) ................................................ 85

J. Parent Consent Form (Spanish) .......................................... 87

K. Human Subject Committee Approval..............................................89 


\section{LIST OF TABLES}

\section{Tables}

Table 1 Demographics of Study's Sample.........................31

Table 2 Descriptive Analysis of Measures....................... 35 


\section{CHAPTER ONE}

\section{$\underline{\text { Introduction }}$}

For many decades, the number of minority students, particularly Hispanics, dropping out from school has been noticeable to say the least (Rumberger, 1995). This considerable portion of students, one of the fastest growing, is showing some very significant deficiencies regarding adaptation and assimilation of the educational system in the U.S., and the results are alarming. These students have in the past and continue in the present to struggle with the educational system, and it is certain, but not clear, that various factors contribute to Hispanics' poor academic performance and not being able to graduate from High School (Rumbaut \& Cornelius, 1995). Some of these factors are organized in three groups. School-Related: (a) Schools failing to meet the specific needs of immigrant students who are trying to incorporate into a new educational system (b) Immigrant students being undereducated (c) Schools struggling to survive financially and having to put on hold the implementation of programs to help immigrant students.

Parental-Related: (a) Lack of parental involvement and communication with schools (b) Lack of communication between parents and students and vice versa (c) Lack of support regarding Students' interest in school and of orientation from parents (d) Low Socio Economic Status of immigrant Hispanic families. Student-Related (a) Lack of attachment to their school and teachers and negative perception of the former (b) Struggle of immigrant students acquiring a new identity with out letting go of their heritage and culture (c) Language deficiency from Immigrant Hispanic students (d) Immigrant students' lack of involvement in school programs (e) Lack of motivation and dedication 
from some Immigrant students (f) Immigrant students having to face numerous demands such as studying and taking full control of their education, working, and helping parents raise younger siblings (g) Immigrant students opting to utilize their time and energy in venues that produce short term economic relief : working one or two shifts in a low paying job and making money and not bothering to undergo the struggles of acquiring an education.

The attempt of trying to comprehensibly understand the issues at hand is not simple, and as much as simple answers to complex questions are always prized, we should remember what Einstein is credited with saying: we need to simplify explanations but avoid making them too simple. Any one of us could provide the basis for a simple answer to the question regarding Hispanic student underachievement: the individual and social/economic influence on the individual not to assimilate. It is just not that simple. Against the oversimplification of significant issues, Eugeene (2000) recommends that the approach of Hispanic educational issues should attempt to bring into perspective numerous contributing "causes" that alone cannot account for a phenomenon. He also adds that in an effort to understand the issues and circumstances of Hispanic students, we can move away from superficial "tip-of-the-iceberg" analysis and more fully understand the course of events through more comprehensive articulations of these circumstances.

Thus, this study is an attempt to understand how immigrant students and parents are currently responding to the challenges of dealing with a foreign educational system. The focus is primarily on how students have to manage a sense of identity while they are trying to incorporate to their schools, and how parents are supporting their children and keeping a dialogue with the schools. 


\section{Definition of terms}

Hispanic/Latino: Refers to the people of Latin origin and those whose primary language is Spanish.

Hispanic Immigrant Students: Refers to students who have come to live in the United States and have Spanish as their primary language and includes students from various places of origin such as Mexico, Central and South America, and students born in the United States (first generation) whose parents came from Spanish Speaking countries.

Ethnic Minority: A person or group of people who have a different culture, religion or language to the main one in the place or country they live. 


\section{CHAPTER TWO}

\section{$\underline{\text { Literature Review }}$}

The struggles Immigrant Hispanic students undergo throughout their educational trajectory are numerous, and many factors contribute to the difficulties these students face in completing High School and going on to college. In the remainder of this chapter, three groups of factors contributing to the performance of Immigrant Hispanic students in High School will be examined. The School-related factors will be presented first, which will cover a number of topics that have direct impact on the reasons why so many Hispanic students perform poorly academically and dropout from High School. Parentalrelated factors will be presented next, which will include a section on the importance of parents' active participation in their children's education. Following that, Student-related factors will be presented and issues of membership and belonging, perception of school, identity, self-motivation, and different alternatives immigrant students choose when school is not working for them among other issues will be discussed. This chapter will end with a statement of the problem and proposed hypotheses.

\section{$\underline{\text { School Related Factors }}$}

Mexican Americans have been noted to have the highest high school dropout rates in the United States Hispanic students have indeed struggled in the area of education. According to De la Rosa (1990), historically, the Mexican American population has a long-standing record of poor academic achievement. Also, the U.S. Department of Education (1992) reports that Mexican Americans are the ethnic group most likely to drop out of high school. In 1992, the estimated drop out rate for Mexican Americans was 
$35.3 \%$ versus $8.9 \%$ for White Non-Hispanics and $13.6 \%$ for African Americans (Grant, 1985). The numbers are very alarming and when the question of why are Hispanics dropping out at such high rate is asked, multiple school related factors start rising up. According to Courtney, Mesquita \& Courtney (1995), a disproportionately large number of minority students are dropping out of high school because either they are failing or lack the motivation to complete the academic requirements for high school graduation. McCarthy (1990), on the other hand, provides a different alternative to the problem at hand. He says that the school system, particularly the school curriculum, remains steadfastly monological. For example, while some popular white artist directly incorporate Afro-Brazilian and South African styles into their music, and while minority artists like Spike Lee, Euzanne Palcy and the Afro Asian Black Arts movement in England introduce new ethic themes into television and film culture, American educators have shown a decided lack of enthusiasm for cultural diversity (McCarthy,1990). No wonder then that schools, like universities, have existed as hostile institutions with respect to the cultural identities of students of Latino backgrounds. The fact is that the school system still effectively marginalizes minority youth by limiting their access to instructional opportunity, to an academic core curriculum, and so on (Courtney et al., 1995). As Linda Grant (1985) in her ethnographic studies of desegregated schools has shown, there is de facto segregation at these schools with respect to such variables as access to teacher time and to the general material resources made available to minorities in the school setting. On another study, Grant (1984) argues that the concentration of Latino and African American students in dead-end, non-academic tracks not only contributes to minority failure but also facilitates the disorganization of minority 
identities by structurally designating these students as disproportionately

"underachievers" and "at-risk."

Another question that often arises is how do these students do while they are in school. Hispanics are held back a grade level at three times the rate of the general student population (Rumberger, 1995). From roughly third grade to eighth grade, academic achievement drops off significantly for Hispanics and Blacks as compared to whites. The unfortunate result is that 40 percent or more of Hispanic and Black students are one grade level or more below expected and normal achievement levels by the eighth grade. This revelation, in concert with the previously discussed high school completion and drop out data, raises substantive educational concerns. Also the data indicate that math and reading achievement in Hispanic and Black students is two to three times less on the National Assessment for Educational Progress (NAEP) measures of moderately complex procedures and reasoning. Such data suggest that the academic and intellectual quality of education of education that Hispanics and blacks receive is substantially different.

In many school districts across the U.S., especially in suburban areas, their priorities and concerns are not necessarily to create programs to accommodate immigrant Hispanic students or to develop better strategies to better serve academically disadvantaged minority students. Instead, they are concerned about the bare necessities, for example, windows, books, typewriters, heating buildings, working bathrooms, lighting, and a renovated building (Kozol, 1985). These schools have been transformed into institutions that must spend valuable time seeking the resources for basic survival. They are much like developing countries that beg for grants, loans, and so on from one source after another. They do so only because the basic resources are not provided by 
present founding structures and formulas. In fact, those structures and formulas are working to their disadvantage. These students attend schools in cities and taxing entities in which competition for tax dollars is great. These same communities have high unemployment and underemployment and are pressed to provide a higher level of related social services (Waggoner, 1991). These variables directly affect the resources that can be directed to education. Most directly, students in these schools are relatively under funded. In a now famous 1968 legal case, Demetrio Rodriguez, a parent of the Eaglewood School district in San Antonio, Texas, argued that his children were underfunded relative to children in an adjacent school district, only a few miles away from his own. The Eaglewood School District (96 percent nonwhite) residents paid a higher tax rate than residents of the nearby district, a predominantly white school district and community. Yet they were able to generate only $\$ 37$ for each pupil. With resources provided by the state, Eaglewood was able to spend $\$ 231$ per student on a yearly basis. The neighboring school district generated $\$ 412$ per student drawing on its locally lower tax rate and, with resources from the state, was able to generate a yearly per pupil expenditure of \$543. This amounted to over a 100 percent differential (Eugeene, 2000). In his article Wehlage (1989) discusses how American educators as well as the public have been ambivalent throughout the twentieth century about what, if anything, can be done about the "early school leaver," or dropout. Regarding this issue, Finn (2004), argues that to the extent that dropping out of school is caused by social factors originating beyond school, the symptom is not likely to be eradicated by school-based remedies. He goes on to assert that the problem of minorities dropping out from schools exists not because of deficiencies in the school but rather because of deficiencies in 
individuals and families. Wehlage, (1989) argues that by focusing exclusively on personal and social characteristics shared by dropouts, certain research makes it appear that dropouts are deviant, deficient, or negligent with regard to school. School, as an institution appears healthy, rational, and performing appropriate for students, except for a few deviants who are incapable of succeeding. Moreover, this focus contributes to a pathological view of these youth and deflects attention from the school itself. He goes on to say that research has not encouraged the possibility that schools themselves may be part of the problem.

Demographic information indicates that diversity in our schools is a recent but explosive and long term phenomenon. Latinos today account for more than 25 percent of all students attending central city schools and 14 percent of the public school population nationwide (Eugeene, 2000). Examining a ten-year span between 1990 and 2000, Latinos have attained the highest rate of population growth in American history. More specifically, the population increased by 58\%, from 22.4 million in 1990 to 35 million in 2000. Having the demographics into perspective, another issue that directly relates to the performance of Hispanic students is school personnel. The issue of who is directly interacting and serving Hispanic students is of relevance because teachers, administrators, and other educational professionals receiving their training over a decade ago were not encumbered by the challenges facing pre-service teaching candidates today. They did not need to be ready to respond the challenge presented by a highly diverse student body (Eugeene, 2000). Moreover, the vast majority of teachers and administrators in the school system are white. In fact, Eugeene (2000) indicates that for the 1993-94 school year, of the 2.6 million public and private school teachers and the 103,000 school 
administrators, over 88 percent were white, and less than 12 percent were non-white and Hispanic- 8 percent black, 3 percent Hispanic, and less than 1 percent American Indian, and Asian or Pacific Islander. Rendon (2003) also adds that very few scholars address the issues related to recruiting and retaining Latino faculty and administrators. What this creates is a disproportionate balance between the percentage of minority students attending schools and the faculty and staff in charge of educating these students.

Referring to teachers and counselors concretely, Losey (1997) speaks of certain attitudes and notions that need to be eradicated. He states, "from grade school through community college, Mexican American students interact with teachers and counselors who underestimate their abilities and discourage them from pursuing their aspirations" (p. 3). Ruiz (1997) in a recent study found that immigrant students receive lower grades and are judged by their teachers to have lower academic abilities than native-born students. Flores-Gonzales (2002) indicates that unsuccessful teachers, lacking an awareness of students' lives, interpret students' lack of engagement in school as a signal that "they do not care," and refuse to waste their time and energy on what they perceive to be "lost causes." Ortiz (1988) adds that sometimes teachers even ignore their Mexican American pupils by "forgetting" to call on them when everyone else is given a chance to read aloud or by failing to include them in groups or teams. Moreover, teachers have also been found to avoid eye contact, physical closeness, and other types of interaction with Mexican American Students.

In their research Flores-Gonzales (2002) indicate that the basis for [Hispanic students'] failure is due to defective organization of lessons and activities based on teachers' unexamined attitudes and beliefs about the perceived "deficiencies" of minority 
and poor students and their families. In his article Ruiz (1997) indicates that to the extent that schools consistently exclude the students' home experiences from the curriculum, alienate their families and discourage their participation in the education of their children, transmit in an authoritarian way standardized curriculum, and bias their assessment of minority children to ensure that some "problem" will be found in them, minority students will be disabled. Suarez-Orozco (1989) narrates his view of school counselors dealing with immigrant students during his fieldwork research. He states that, "rather than concern herself with developing an integral program of study for students, the Spanishspeaking counselor placed students in classes in almost an assembly-line fashion, without regard for their individual prior record of study, current level of functioning, or aspirations for the future" (p. 5). Mier and Stewart (1991) indicate that separating Hispanic students from Anglos begins the process of separation that eventually produces inequalities in education. They note that special education assignments for Hispanics are used in the same manner as punishment of Hispanic students, for the purpose of removing them from regular classes. Flores-Gonzales (2002) offers an alternative to the separation of students and indicates that despite the overwhelming evidence that grouping practices are flourishing, his initial preference is to ban all academic grouping. He declares that cooperative learning, where students form teams to assist each other, is one approach that has received a great deal of attention.

Another issue that arises in the literature review is the challenges schools are confronting in terms of the students they have to educate. While immigrants have affected all aspects of American life, nowhere is the changing demography of the United 
States more keenly felt than in education. First and second generation immigrant children are the fastest growing segment of the U.S. population under 15 (Fix and Passel, 1994). With over 90 percent of recent immigrants coming from non-English speaking countries, schools are increasingly receiving students who do not speak English at home and who have little or no proficiency in English. There has been an increase of almost one million immigrants in U.S. public schools (grade K-12) in the last 10 years, approximately 5.5 percent of the public school student population (Rumbaut \& Cornelius, 1995). Furthermore, Approximately 20 percent of Limited English Proficiency (LEP) students at the high school level and 12 percent at the middle school level have missed two or more years of schooling since the age of six; 27 percent in high school and 19 percent in middle school are assigned to grades at least two years lower than age/grade norms (Eugeene, 2000). Experts predict that the greatest increase over the next decade will be in high school enrollments, projected to increase by 15 percent. Thus, schools already struggling with the influx of immigrant students are also facing the strains of high school overall enrollments and language barriers.

What should schools be doing to better serve the minority immigrant Hispanic students? According to Eugeene (2000), The effective school for language minority Hispanic students should encourage them to take risks, construct meaning, and seek reinterpretation of previous knowledge within compatible social contexts that utilize the language and culture of students as a learning platform. He adds educators should expect that young children will take several years to learn a second language to the level of a native speaker. In her book, Flores-Gonzales (2002) offers various alternatives for schools regarding the support of Latino students. First, schools should help kids develop 
numerous and deep relationships with their teachers and peers, and that these relationships should be characterized by caring, respect and dignity. Second, besides being challenging, the curriculum should be meaningful to the students. Students find the curriculum meaningful when they can relate to the lessons because they speak to their reality. Third, schools should make each student "count," and make them feel like they are "somebody" and not "invisible." Fourth, schools should help students develop multiple identities connected to school. For example, schools should create additional extracurricular options and after school programs that do not require that students meet criteria such as grades or skill level in order that the vast majority of students have an opportunity to participate. Fifth, schools should create multicultural programs that can focus on the learning and promotion of Latin American and other cultures. This could later on result in the creation of a multicultural center. Pugach (1998) suggests that schools can function not only as centers where students gather to learn, but also as key sites for the construction of community identity and inclusion. Purkey \& Smith (1983) also provide some insight into the attributes of successful schools. These include a strong sense of leadership; high expectations of students; school-wide staff development; parent involvement and support; and a sense of community.

According to Gonzalez and Padilla (1997), understanding the academic failure of Hispanic students solely from a school point of view is greatly limited, for there are other numerous factors that contribute to the low performance of this particular population.

What the research suggests is that Hispanic students are indeed struggling to assimilate or accommodate to a new School System, and that the schools themselves are having to face many challenges in regard to accommodating the high percentage of 
Hispanic students enrolling in high schools. The schools are to some degree failing to give meaningful direction to these students and in need of more accredited or trained personnel that could better work with these students.

\section{Parental Related Factors}

Parents of Immigrant Hispanic Students face many a challenge when it comes to educating their sons and daughters, especially when they are trying to adjust to a new culture themselves and working hard to sustain their families. Hamann, Wortham \& Murillo (2002) wrote in an article, "Newcomer Latinos are confronted with novel challenges to their senses of identity, status, and community" (p.1). In terms of school issues and parents, Valdes (1996) has noted that Latino parents frequently have different conceptualizations of parent and school responsibilities than the middle-class Anglo who set most U.S. public school policy. When parents are asked what they expect from their children, Suarez-Orozco (1989) states that in his conversations with parents it became evident that they gained a vicarious sense of accomplishment through the efforts of their children. He continued by saying that "Their [parents] most cherished wish was that their children would enter college, and the statement "we want our sons/daughters to become somebody' was often repeated by them" (p. 13). Following the same notion, Ogbu (1978) concludes that a driving force common to most immigrants is the belief that hard work in the new land is certain at least to benefit their children.

Several deficiencies encountered in Hispanic homes have been mentioned in the literature. According to Riessman (1962), culturally deprived children fail in school because they lack an educational tradition in the home and have few books, as well as 
being subject to poor health, improper diet, frequent moving, and noisy TV-ridden homes. In terms of Hispanics living in poverty, studies have shown that low socio economic status (SES) is strongly and consistently associated with poor academic performance. Youth of low SES are likely to live in low-SES neighborhoods that are characterized by poor housing conditions, inadequate public and social services, and schools that lack sufficient funds to provide a high quality education. A higher proportion of Hispanic children (41\%) live in poverty compared to Whites (13\%) (Hechinger, 1992). Therefore, poverty is a risk factor that places a significant proportion of Hispanic at risk for negative outcomes.

Parental Support for Hispanic Students is of much relevance when assessing progress in students. In her article, Gandara (1995) reported that family support and individual persistence were the factors that contributed most to students' academic success. She also found that parental involvement, by means of instilling high standards and assisting with homework when possible (despite the average level of fifth grade education), was also identified as an important factor that influenced academic achievement. Cummins (1984) also argues that parental participation is a critical element in the success of minority students but warns us that schools can sabotage it. In an ethnographic study of parental involvement, Lareau (1989) contrasts the behaviors and attitudes of high-status parents with those of low-status parents. She found that the former group assumes a proactive role whereas the latter's participation is passive. Because of their high status, based on their professional roles and social class, these parents exercise the power that their hegemonic status affords. Lower status parents, on the other hand, do not exercise power with respect to teachers and schools because of their disabling effects 
of being in a low social class. This dominant silencing status is sustained by society accepting the status quo (Gramsci, 1971). The paradox of parental involvement of minority parents is that teachers negatively view their traditional non-involvement but also respond negatively when they challenge the status quo and begin to behave like high-status parents (Shannon, 1996).

In their article, Scriber, Young \& Pedroza (1999) state what it means for parents to be participants in their children's education. They affirm that parental involvement means participating in activities such as school events, meetings, workshops, and governance activities, and working as teachers' aides, tutors and school advocates within the larger school community. They go on to suggest that checking homework, assignments, reading and listening to children read, and obtaining tutorial assistance are among the many activities parents can do informally at home with their children. The importance of parents' involvement in their children's education appears to be a constant among different studies. For instance, Delgado-Gaitan (1988) found that Chicano students whose parents were involved in their education were more likely to stay in school. In his study, Erickson (1987) interviewed teachers who defined parental involvement as a way of supporting the academic achievement of students at school and at home. Nonetheless, parents of minority students often face certain barriers regarding involvement with their children's education. Scribner et al. (1999) tells us that some of the challenges these parents face are inadequate transportation, lack of interpreters, and an unwelcome school environment. 
In Sum, the research indicates that immigrant parents find it very difficult to acculturate and become a part of a new educational system where their participation is asked. Parents do not generally know how the educational system works, and they lack the confidence, energy or motivation to contact and be active members of their children's school. The research supports the idea that the more support Hispanic parents are able to provide to their children at home as well as participating in school programs (as volunteers, tutors, aides, etc.), the more their children will have a chance of being successful at school.

\section{Student Related Factors}

\section{School Membership}

Among the factors that impede Hispanic students from succeeding in school we find the issue of School Membership, which according to Wehlage (1989) is more than simple technical enrollment in a school. It means that students have established a social bond between themselves, the adults in the school, and the norms governing the institution. He goes on to say that Membership is achieved when students are attached, committed and involved in the activities of the institution, as well as believe in the institution. Brophy (1983) states that it may be that the perception the individual has of his or her educational environment determines how likely they are to become involved in activities at that institution. Goodenow (1992) believes that a student's sense of belonging has a reinforcing effect on positive academic behavior. Thus, a student who feels a sense of belonging to the school environment may become more engaged and exhibit greater effort on academic tasks, which results in greater acceptance and 
belonging from others in the school environment. A supportive context is likely to foster a student's sense of efficacy and achievement (Goodenow,1992). Moreover, a sense of belonging may reduce a student's feelings of disengagement, which may lead to dropping out of school. A student who cannot identify with peers and teachers due to disparities in cultural background may also feel disengaged from school and thus perform poorly in school (Gonzales \& Padilla, 1997).

When applying these concepts to Hispanic/minority/at-risk students, the issue that arises for students is "incongruence" in the cultural match between the students and the institution. Incongruence between students and school applies to all who identify themselves as out of the mainstream in some way (Wehlage, 1989). Also, the perception Hispanic students have of the cultural mismatch that exists between them and the dominant group creates conflictive barriers for the minority students. Losey (1997) contends that students who come to school already familiar with the norms and rules of school interaction- that is, primarily mainstream, middle class, Anglo American students, have an advantage over those who do not because they are familiar with the discourse appropriate to the classroom and therefore can concentrate on the content of the teacher's lesson. Therefore, students who are unaccustomed to the typical structure of the classroom interaction must learn this structure as well as the content of the lesson, a double burden. Hispanic students also have difficulties establishing and maintaining a collaborative relationship with teachers at school. Mexican American students interact with their teachers much less than their Anglo American counterparts. Accounting for that, experts argue that Mexican American students talked less because of their teachers' relative lack of attention to them (Wehlage, 1989). 


\section{Identity}

Another issues that arises is the identity of those minority students who are undergoing a foreign and predominant White educational system. Mc Carthy (1990) affirms that minority cultural identities are not fixed or monolithic but multi-vocal, and even contradictory. These identities are indeed "fluid" and derive from the historical grounded experience and practices of oppressed minority groups (Gonzales \& Padilla, 1997). They reflect the process by which these practices and experiences come to be represented, reconstructed and reinvented in daily life, in the school and the school curriculum. In terms of academic success and identity issues, one difficulty observed in minority students is the dilemma of striving to succeed and maintaining their own sense of who they are at the same time (Mc Carthy, 1990). Racial and ethnic minorities (and lower-income students) tend to experience difficulty maintaining a racial/ethnic identity and academic success simultaneously because academic success is perceived by them as characteristically "White" behavior (Fordham, 1988). For racial and ethnic minorities to succeed academically implies the adoption of "Whiteness," while forsaking their ethnic identity. McLaren (1994) refers to an ethnic minority's success in school as cultural or racial suicide because in order to succeed, these students must reject their culture in favor of "White" culture. Other studies add that high achieving minorities pay a high price because they are accused of "trying to join the enemy," or "acting White," and tend to be more depressed, less politically aware, less assertive, and more conformist than low achievers (Fine, 1991). 
Opposing the previous points regarding achievement and identity, we find the following studies. Recent research finds that academic success does not necessarily come at the expense of ethnic identity for all groups (Flores-Gonzales, 1999). Focusing on students of varied ethnic and class backgrounds, these studies show that racial/ethnic minorities do not have to choose between performing well in school or maintaining their ethnic identity; they can be "ethnic" and "model" students simultaneously. These studies also show that racial/ethnic minorities do not necessarily associate school success with "Whiteness," nor are they subjected to peer pressure that lead to not doing well in school. Rather, they suggest that many racial/ethnic minorities view school success as a middle class trait, and since they are, or aspire to be, middle class, achieving in school is appropriate behavior for them (Flores-Gonzales, 2002).

The issues of identity of Hispanic/minority students are everything but simple or easy to understand since they encompass a wide variety of variables. Flores-Gonzales (2002) formulated two new sets of identities for Hispanic students. She calls these "school-kid" and "street-kid" identities, and argues that either of these identities is constructed. The school-kid identity, more than an identity bounded to school, represents an image of how these youths view themselves and how they want to be viewed by others. Students are successful in school to the extent that they are able to adopt and sustain a school-kid identity. On the other hand, students who do not become school kids and who behave contrary to school norms are given the name of street-kids. This term is used in order to identify youth who take non-school-oriented identities and who engage in behaviors contrary to accepted norms. Flores-Gonzales (2002) adds that school can make or break the school-kid identity by offering different educational experiences to 
students (access to extracurricular programs, close relationship with teachers, challenging classes). Her work points to the ways in which school produces school-kids and streetkids by giving or denying them certain conditions needed to become engaged in school.

Newmann, Wehlage, and Lamborn (1992) point to some factors that affect students' engagement in school. According to them, students become engage in school when they feel competent; that is, when they acquire the intellectual and social skills that lead to adequate performance in school. To achieve competence, they must develop a sense of membership or belonging to school through meaningful interactions with teachers and peers. They must also find work to be meaningful, connected to the real world, engaging, fun, and rewarding. On the other hand, Valenzuela (1999) points out how some school do not really provide the above mention factors to help Hispanic students progress in school. She argues that many Mexican American students were frustrated by classes that were boring and unchallenging, and teachers who seemed not to care about them. In this sense, school directly contributes to the development of streetkids. After all, it is the students who lack connections to school who take on street identities and end up dropping out (Flores-Gonzales, 2002).

The early years of education and how minority Hispanic students experience those years are crucial in the development of school or street identities, since the experiences that students have there determine to a large extent how they conceive and express their student identity (Mc Carthy,1990). For most minority students, the identities they form in Elementary school are a reflection of what they will later become (stayer, leaver, or returner) (Flores-Gonzales, 2002). That is, which identity students assume in elementary school has repercussions on their staying in school or dropping out. In 
concrete terms, we have the stayers whose recollection of elementary school has an almost nostalgic twist to them. They long for their elementary school days, mainly because they are marked with academic and social accomplishments. Most stayers also had close and often personal relationship with a favorite teacher. On the other hand, the formation of a street-kid identity in the early grades can be a response to their marginal status at school due to the lack of social support, prestige, and rewards; their inadequate performance of the student role; and the absence of meaningful relationships with peers and teachers (Flores-Gonzales, 2002).

\section{Motivation}

Lack of motivation from Hispanic students is also a strong factor related to poor academic achievement. What contributes to this issue is the environment these students experience at school, specifically in their classrooms. Losey (1997) states that Mexican American students seem to prefer a collective or cooperative classroom structure over an individualistic, competitive one, and they respond better to opportunities to be responsible than to formal authority structures. Adding to this idea, Weinstein (1986) notes that Mexican American students whose teachers draw on their students' interests and experiences when designing assignments also have a greater success. These students were given challenging assignments on topics of interest to them, and the lessons were successful because students were allowed to take part in more class discussions and small groups assignments and to develop and provide input on their own assignments.

Recently, more research of classroom interaction have come to recognize that forces other than those considered "culturally determined" may be involved in what is 
found in the classroom related to lack of motivation. Rosenthal \& Jacobson (1968) acknowledge that classroom interaction is also the medium by which teachers express their expectations for students, particularly on the basis of race, ethnicity, gender, linguistic competence in English, and socioeconomic class may be observed. Teacher may interact differently with students whom they perceive to be high achievers than with those they see as low achievers (Weinstein, 1986). Perceptions of high and low achievement may be directly or indirectly related to social class, language use, ethnicity, and gender (Coates, 1986). As a result, what may be seen in Hispanic students in terms of their lack of motivation could also be explained by what the teachers' perspective is regarding a specific student. The content of interaction in the classroom can also influence student-teacher interaction. Weinstein (1986) cites a lack of relevant curriculum, textbooks, and other materials plus teachers untrained to incorporate the experiences of Mexican American Students into class discussions as contributing to the feeling in these children that school is alien to them and of little relevance to their lives, beginning a cycle of "lowered interest, decreased participation, poor academic performance and lowered self-esteem" (p. 44).

In relation to academic success and failure, it has been documented that individuals generally attribute these outcomes (educational achievements) to one or more of the following causes: ability, effort, task difficulty, luck, mood, and help or hindrance from others (Cooper, \& Burger, 1980; Weiner, 1985). These causal ascriptions have been further classified along three dimensions: locus (internal vs. external), stability (fixed vs. variable), and controllability (controllable vs. uncontrollable) (Weiner, 1985). The locus of cause has also been linked to esteem-related affects such as pride; the stability 
dimension has been linked to expectancies for success; and the controllability dimension has been linked to interpersonal evaluation (Graham, 1986). Attribution theorists have demonstrated that low-and high-achieving students differ in their causal attribution patterns. Weiner (1985) and Kukla (1972) have demonstrated, for example, that high achieving students attribute their success to a high degree of ability and effort.

Furthermore, they consider their failures to be the result to a lack of effort on their part. By contrast, low achieving students tend to perceive failure as the result of their own lack of ability, but they consider success to be the result of external factors, such as task ease or luck (Weiner et al., 1971). These studies indicate that individuals tend to have different attributional styles, which, in turn, influence how they respond in a given situation.

In the quest to understand the factors contributing to Hispanic students' lack of achievement in school, researchers also focus on the positive strategies that can aide these students to better perform in school. The key to school success, some argue, lies in the students' ability to manage their multiple "worlds": home, school, and neighborhood (Davidson, 1996). Phelan, Davidson, and Yu (1998) conclude that successful students are those who effectively manage transitions between these worlds, and particularly those whose worlds are incompatible.

\section{Extracurricular participation}

The significance of extracurricular participation for Hispanic/minority students is a factor that can help these students stay in school and/or have a better school experience. It is found in some studies that students who participate in extracurricular activities are less likely to drop out of school. Zill (1995) found that the drop out rate was lower among 
at-risk students who had participated in extracurricular activities. Oliver (1995) also suggests that individual's participation in extracurricular activities can build young persons' interest in school, strengthening their sense of identity, and allow them greater exposure and self-satisfaction from service. Often the debate regarding extracurricular activities centers on which type of activity appears to have the most positive influence on the individual. Research suggests that not all extracurricular activities affect student retention to the same extent, with participation in athletics and fine arts programs most likely to reduce the likelihood of dropping out. In a study commissioned by the Department of Health and Human Services, Zill (1995) found that students who did not participate in after-school activities were $57 \%$ more likely to drop out by their senior year, $49 \%$ more likely to use drugs, and $27 \%$ more likely to have been arrested. Many have stated that athletic participation increases an individual self-esteem, which not only has a positive effect on the students' school involvement but also may encourage further educational plans including college enrollment and college attainment (Braddock, 1981). Moran, Yengo and Alguier (1994) found that not only did participation of Mexican American students in college sponsored extracurricular activities produce a beneficial effect on the socio-emotional adjustment of high-risk freshman, but it also can increase the sense of belonging.

\section{Language}

Language is one more factor that plays a role in the discussion of poor performance of Hispanic/minority students in the school setting. Clearly much of the controversy about education for Hispanics students centers around language. Spanish has 
proven to be the most long lasting foreign language in the United States (Grebler, Moore, and Guzman, 1970). The linkage between language and education is simple: students with limited ability to communicate in English are at a disadvantage in most U.S. Schools (Mier and Stewart, 1991). Macedo (1997) points out the importance of maintaining the native language for minority students to better assert their identities. He adds that without the cultivation of their native language, and robed of the opportunity for reflection and critical thinking, linguistic minority students find themselves unable to recreate their culture and history. Various researchers find fault with the strong movement to promote an English-Only methodology of teaching, excluding the use of immigrant students' use of their own language (Macedo,1997). First, if English is the most effective educational language, how can we explain that over 60 million Americans are illiterate or functionally illiterate? (Kozol, 1985). Second, if education solely in English can guarantee linguistic minorities a better future, as educators, like William Bennett promise, why do the majority of Black Americans, whose ancestors have been speaking English for over 200 years, find themselves still relegated to ghettos? It is naïve to think that the acquisition of the English Language alone will, somehow, magically eclipse the raw and cruel injustices and oppression perpetrated against the dispossessed class of minorities in the United States (Macedo, 1997). Despite the pros and cons of the importance of the acquisition of the English language, Gramsci (1971) states that without the mastery of the common standard version of the national language, one is inevitably destined to function only at the periphery of national life and, especially, outside the national and political mainstream. 


\section{$\underline{\text { Alternatives }}$}

In some cases, Hispanic-immigrant students get overwhelmed by the difficulties of navigating in the school system and develop some alternatives or routes regarding their future. Low achievers are said to have developed a critical consciousness that reject the false promises of the educational system. These students may have high regard for education, but they do not believe that it is a means for social mobility. For them hard work in school does not necessarily translate into success later in life because structural forces such as gender, class, race, and ethnicity circumscribe one's opportunity (FloresGonzales, 2002). Another researcher agrees with the previous notion and adds that most detrimental to immigrant students' success in school is their diminishing belief that they have an opportunity to obtain a quality education equal to that of Whites, paired with a growing belief that for them, a formal education is not the means to socioeconomic prosperity (Bernal, Saenz \& Knight, 1991). In some other cases, the "parts" are not in place to facilitate a true opportunity for some minority youth. Waggoner (1991) states, some young students who have completed fewer than 12 years of schooling before immigrating never enroll either here because they arrive at age 16 or later and need to begin earning to support themselves and their families or because school programs do not meet their needs.

Thus, the literature indicates that issues such as membership and identity for Hispanic students do play a big role on how students respond to the educational system; in this regard, Hispanic students who perform poorly academically are indeed detached from school, have no meaningful relationships with teachers, and are struggling to 
maintain a sense of who they are and who they will become. Moreover, the experiences Hispanic students will have early on in school will largely determine if they will become "school or street" kids and whether they will stay or not in school. The literature also suggests that those Hispanic students who participate in extracurricular activities and those who are able to manage their different "worlds" will remain and perform better in school. 


\section{Statement of the Problem}

The literature presented supports various notions that are directly related to students' poor academic performance and high levels of dropouts: (1) the school system's inability to effectively approach parents of Hispanic children and the school system's limited understanding of the wide Hispanic student population; (2) the parents of Hispanic children lacking the connection with the school system and the capacity to guide their children academically; (3) the students lacking membership and motivation and having a confused sense of identity along with problems with language and limited participation in extra curricular activities. Consequently, if all these factors play such as huge part in immigrant Hispanic students' poor performance in school and high levels of drop outs, it is of vital importance that we look at how students and their parents are currently experiencing the school system and analyze what factors continue to be impeding students from successfully staying and performing in school. Therefore the purpose of this study is to better understand how the above-mentioned factors may be impacting students' ethnic identity, academic achievement and adjustment to the American educational system. 


\section{Hypotheses}

The hypotheses for this study were as follows:

Hypothesis 1:

It was hypothesized that students' overall ethnic identity would correlate significantly with students' psychological sense of school belonging. Specifically, it was predicted that a stronger ethnic identity would correlate with a higher sense of school belongingness for these students.

Hypothesis 2:

It was hypothesized that students' psychological sense of school belonging would be positively related to their overall GPA in school, and to their parents' number of years in the U.S.

Hypothesis 3:

It was hypothesized that students' attitudes toward other ethnic groups would significantly relate to parent's attitudes toward other ethnic groups.

Hypothesis 4:

It was hypothesized that students' psychological sense of school belongingness would positively relate to parent's sense of connection to their child's school and belief about their child's connectedness to their school. 


\section{CHAPTER THREE}

\section{$\underline{\text { Method }}$}

\section{$\underline{\text { Participants }}$}

Subjects were 35 immigrant Hispanic students who were currently attending San Luis Obispo High School, and 31 parents of immigrant Hispanic students. Students participating in this project range from grades ninth to twelfth. They all spoke Spanish as their first language and are in the process of learning English (from level I to VI). Parents are from other countries and also speak Spanish as their first language. The students were chosen from a list generated by the school's data system. This list included only students who classified themselves as Hispanic and from that list I selected the students who spoke Spanish as their primary language and were born outside of the U.S.. Out of those 45 students who met the criteria, only 35 participated in this study. Participation was voluntary and no rewards or incentives were offered to the students for their participation. Of all the students participating, 14 were males and 21 were females. There were 8 Freshman, 13 Sophomore, 10 Juniors, and 4 Seniors. (See Table 1 for Demographics). 
Table 1

Demographics of Study's Sample.

\begin{tabular}{|c|c|c|c|c|c|}
\hline Characteristics & $N$ & Minimum & Maximum & $M$ & $S D$ \\
\hline \multicolumn{6}{|l|}{ Gender } \\
\hline Male & 14 & & & & \\
\hline Female & 21 & & & & \\
\hline Age & & 15 & 18 & 16.14 & .84 \\
\hline Grade & & 9 & 12 & 10.25 & .88 \\
\hline GPA & & 1.30 & 3.50 & 2.31 & .54 \\
\hline Parent's Years in the US & & 1.00 & 12 & 4.85 & 2.93 \\
\hline
\end{tabular}

Parents of participating students were selected and invited to participate. The criteria for participating was that they spoke Spanish as their primary language and that they had moved to the United States from a Spanish speaking country. These parents were sent a letter or called home to explain the nature of the study and to request their participation. The students participating provided the addresses of these parents as well as their phone numbers. Out of those participating parents, 2 were males and 29 were females $(N=31)$. 


\section{Materials and Procedure}

Two types of questionnaires were given to the students and a different questionnaire was given to the parents. Permission was asked and granted by the San Luis Obispo High School's principal to conduct the questionnaires and for the voluntary participation of students at the school. Students were given the questionnaires at the school site, and permission was asked to the English Language Development (ELD) teacher to allow the students participating in this project to answer the questions in his classroom. Students were notified to gather during lunch or at the end of school in the ELD classroom to fill out the questionnaires. Parents' questionnaires were administered at their homes, and appointments were arranged via phone or by oral report form their respective sons and daughters. All procedures and tasks related to students and parents were conducted in Spanish.

Once the students came into the ELD classroom, they were given basic instructions as to how to fill out the questionnaires and explained the scales being used. They were asked to use their pens (no pencils in order to avoid the manipulation of answers) and given as much time as needed to finish the questionnaire. Students were reminded that their participation was voluntary and that they had the right to refuse to answer any of the questions and to leave the classroom at any point during the process of completing the questionnaires.

Once the parents agreed to participate and the appointment was made, I proceeded to visit their home. They were reminded of the nature of the study and the anonymity of it. They were also informed that their participation was free and voluntary; that they had the right not to answer any question if they did not want to, and that they could stop at 
any minute. The questions were read to the parents, and I wrote the responses in the space provided after each question. Parents were told their answers could be as extensive or brief as they wanted to.

\section{Instruments}

The Multigroup Ethnic Identity Measure (MEIM): Developed by Jean S. Phinney (1992), this questionnaire, composed of 23 questions, was used to elicit information from the students based on their particular experiences about their ethnicity and/or their ethnic group and how they feel or react to it. The MEIM consists of 14 items assessing three aspects of ethnic identity: positive ethnic attitudes and sense of belonging ( 5 items); ethnic identity achievement (7 items); and ethnic behaviors or practices ( 2 items); Also included in the questionnaire are six items assessing other group orientation. Over all reliability of the 14-item Ethnic Identity Scale was .81. For the 5-item AffirmationBelonging subscale, reliability was .75. For the 7-item Ethnic Identity Achievement subscale, reliability was .69. The separate 6-item scale for other-group orientation showed lower reliability than the Ethnic Identity Scale: .71.

The Psychological Sense of School Membership (PSSM): Developed by Carol Goodenow (1993), this questionnaire includes 18 questions, which focused on students' feelings and notions about school in general and what each student thinks about classes, teachers, other students, and overall sense of belonging in the school environment. All items are written in a 5-point Likert format, with choices ranging from not at all true (1) to completely true (5).Internal consistency reliability has been reported as ranging form .77 to .88 for different samples (urban vs. suburban), as well as for English and Spanish versions. 
Parents Questionnaire: This questionnaire was composed of 29 questions, which aimed at gathering information from parents regarding their experience at living in a new country, involvement at school and the types of interactions they have with their children. These questions were derived from the literature and the Students' Questionnaires. The objective was to come up with some kind of relationship between the different sets of responses from children and parents. 


\section{CHAPTER FOUR}

\section{$\underline{\text { Results }}$}

The results of 35 students and 31 parents were analyzed in this study. Descriptive statistics for the measures utilized are presented in Table 2.

Table 2

Descriptive Analysis of Measures.

\begin{tabular}{lcccc}
\hline Measure & $M$ & $S D$ & Minimum & Maximum \\
\hline MEIM Total Score & 3.08 & .39 & 2.21 & 3.71 \\
& & & & \\
$\quad$ Affirmation and Belonging & 3.45 & .62 & 2.00 & 4.00 \\
Ethnic Identity Achievement & 2.84 & .33 & 1.86 & 3.43 \\
& & & & \\
$\quad$ Ethnic Behaviors and Practices & 2.95 & .78 & 1.00 & 4.00 \\
& & & & \\
Attitudes toward Other Groups & 2.84 & .52 & 1.83 & 3.67 \\
& & & & \\
PSSM Total Score & 3.35 & .51 & 2.11 & \\
& & & &
\end{tabular}




\section{Quantitative Results}

\section{Hypothesis 1:}

It was hypothesized that students' overall ethnic identity (as measured by the total score on the MEIM) would correlate significantly with students' psychological sense of school belonging (as measured by the total score on the PSSM). Specifically, it was predicted that a stronger ethnic identity would correlate with a higher sense of school belongingness for these students. A Pearson-product correlation was conducted to test this hypothesis, and it was not found to be significant, $r(35)=.25, p=.15$.

A forced entry multiple regression analysis was conducted to evaluate if any of the subscale scores on the MEIM predicted sense of school belongingness. The predictors were Affirmation and Belonging, Ethnic Identity Achievement, Ethnic Behaviors, and Other-group orientation, while the criterion variable was the total score on the PSSM. The Affirmation and Belonging subscale was the only subscale that was significantly related to psychological sense of school belongingness, $t(34)=2.04, p<.05$. The $\mathrm{R}^{2}$ was approximately .11 , meaning $11 \%$ of the variance on the measure of psychological sense of school belongingness in this sample can be accounted for by students' feelings of affirmation, belongingness, and pride in one's ethnic group.

An independent-samples $t$ test was conducted to evaluate if there were significant gender differences in students' scores on ethnic identity and school belongingness. The results of this analysis showed that there was a significant difference between males and 
females on the MEIM, $t(33)=-2.86, p=.01$, with females $(n=21, M=3.22, S D=.29)$ demonstrating a significantly higher overall score on ethnic identity than males $(n=14$, $M=2.87, S D=.45)$. Furthermore, females $(n=21, M=3.69, S D=.43)$ scored significantly higher on the Affirmation and Belonging subscale, $t(33)=-2.91, p=.01$, than males $(n=14, M=3.11, S D=.45)$. Marginal significance was demonstrated on the Achievement subscale regarding gender, $t(33)=-1.85, \mathrm{p}=.07$, again with female students $(n=21, M=2.93, S D=.25)$ scoring higher than males $(n=14, M=2.72, S D=.42)$.

\section{Hypothesis 2:}

It was hypothesized that students' psychological sense of school belonging would be positively related to their overall GPA in school, and to their parents' number of years in the U.S. A forced-entry multiple regression was conducted to test this hypothesis. Neither variable significantly predicted psychological sense of school belonging.

A Pearson-product correlation was conducted to test if there was a significant relationship between students' GPA and parents' years in the U.S., and this was shown to be significant, $r(35)=.76, p<.01$. This means, the longer amount of time students' parents were in the U.S., the higher these students' GPA.

An independent-samples $t$ test was conducted to evaluate if there were significant gender differences in students' GPA and parents' years in the U.S. Male and female students did not differ significantly in their GPA's, $t(33)=-.313, p=.76$, nor in their parents' length of time in the U.S., $t(33)=-.76, p=.45$. 


\section{Hypothesis 3:}

It was hypothesized that students' attitudes toward other ethnic groups (as measured by the MEIM subscale, Other-group Orientation) would significantly relate to parent's attitudes toward other ethnic groups (as measured by three questions: Does your son/daughter relate to teens from other ethnic groups? Do you as a parent have any social interaction with people from other ethnic groups? Would you as a parent accept or encourage your son/daughter to relate to teens from other ethnic groups?). A Pearsonproduct correlation was conducted to evaluate this relationship, and a negative, nonsignificant relationship was revealed, $r(31)=-.27, p=.14$. While this relationship was not significant, the direction of the correlation suggests that the higher the students' orientation to other ethnic groups, the lower the parents' orientation to other ethnic group relationships.

Hypothesis 4:

It was hypothesized that students' psychological sense of school belongingness (as measured by a subset of questions from the PSSM: questions 1, 5, 6, 10, 13, 14, 17) would positively relate to parent's sense of connection to their child's school and belief about their child's connectedness to their school (as measured by the following six questions: How informed are you about your child's school? So you think your son/daughter feels he/she belongs at his/her school? How often do you talk to your child about school? Do you think your child is understood and respected by his/her teachers? How often do you attend school related activities? What does your daughter/son think about their education and school in general?). A Pearson-product correlation was 
conducted to evaluate this relationship, and a negative, nonsignificant relationship was revealed, $r(31)=-.19, p=.31$. Again, while not significant, the direction of the correlation suggests that the higher the students' sense of school belongingness, the lower the parents' sense of connection to their child's school and belief about their child's connectedness to their school.

\section{Qualitative Results}

Parents' responses indicating current motivation for being in this country and their understanding of the educational system as well as their level of involvement with their children are presented below:

Of the 31 parents interviewed, 55\% of them answered their motivation for living in the United States was to have a better quality of life in general. Parents whose response indicated their main motivation was that of increasing their financial means were $32 \%$. A small number of parents responded their purpose for immigrating to this country was to re-unite their families (one or two of the parents was already living in the United States), 13\%. When parents were asked what they found most difficult living in the United States, $64 \%$ answered language, $32 \%$ said kids' behavior, $22 \%$ indicated transportation, another $22 \%$ said understanding laws, $16 \%$ said culture and lack of legal documentation. (Parents were allowed to provide more than one response and the percentages might include multiple responses from parents). When parents were asked if they had plans or were contemplating the idea of going back to their country of origin, $84 \%$ responded yes, $6 \%$ said no. The remaining, 10\% said they did not know. 
When parents were asked what they saw their children doing in 5 years from now, this is what they answered: Of the 31 parents interviewed, $63 \%$ responded they saw their children working right out of high school. Twelve percent of parents responded they saw their kids graduated from a four-year university and working as professionals. Six percent of parents answered they would like their kids to be attending or finished a vocational school and working. Nineteen percent of them did not know what their kids would be doing 5 years from now. Parents were also asked how much they were informed about their children's school (Principal, teachers, counselors, resources...) and $62 \%$ of parents answered they were not informed. Thirty two percent of parents stated they were somewhat informed and $6 \%$ indicated they were very informed about their children's school. Another question parents were asked was how much time they talked to their kids about school. Forty eight percent of parents answered rarely or never. Twenty two percent of parents answered sometimes, and 29\% answered often. When asked how often parents attended school related activities, $16 \%$ of parents answered always, $26 \%$ of parents answered sometimes and $34 \%$ of parents answered never. Another very interesting question asked to the parents was if their children had ever expressed to them the desire to leave school. Forty five percent of parents answered yes and 55\% answered no. As a follow up question, parents were asked to consider what would their reaction be should their kids told them they wanted to leave school. Nineteen percent of parents answered they would try to talk to them and encourage them to continue. Another $19 \%$ of parents said that would be their kids' decision to leave school. Twenty six percent of parents reported they would just feel mad or sad. Twenty two percent of parents said they did not know what they would do or react. 
As a way of trying to get a sense of what immigrant Hispanic kids do when they get home, parents were asked what activities their kids engage in after school. The main responses are as follows: busy doing homework, 19\%; Kids mainly watching T.V.,22\%; Kids spending most of their time outside of the home with friends, 39\%; and Kids doing other things, 20\%. Parents also answered what they thought their kids' notion of school was (if they thought their kids liked school or not). Thirty two percent of parents answered their kids liked school. Forty five percent of parents answered their kids did not like school and 22\% parents said they did not know. 


\section{CHAPTER FIVE}

\section{$\underline{\text { Discussion }}$}

While the proposed hypotheses of this study did not hold up as predicted, some of the trends found in this study are very interesting in regards to the interconnectedness that exists between schools, parents and their children. It was hypothesized that students' overall ethnic identity would correlate significantly with students' psychological sense of school belonging. It was also predicted that students' psychological sense of school belonging would be positively related to their over all GPA in school and their parents' number of years in the U.S. Another prediction was that students' attitudes towards other ethnic groups would significantly relate to parents' attitudes towards other ethnic groups. Lastly, it was hypothesized that students' psychological sense of school belongingness would positively relate to parents' sense of connection to their child's school and belief about their child's connectedness to their school.

The Affirmation and Belonging subscale of the MEIM was the only subscale that was significantly related to psychological sense of school belongingness. The Affirmation and Belonging subscale is designed to assess the feelings and attitudes students have towards their own ethnic group. Scoring high in this subscale would mean that students have positive feelings towards their own ethnic group. This subscale focuses on the degree in which teens feel attached to their own ethnic group. It was also found that females scored significantly higher on overall ethnic identity, affirmation and belongingness, and the achievement subscales. What this tells us is that females are doing better than males at feeling good about their own ethnic group. Females, the data suggest, 
feel more attached to their ethnic group and have developed a clearer and more secure sense of ethnic self than males. In sum, females in this study appeared to have a more developed ethnic identity than their male counterparts.

The findings in this study aim at explaining the relation that exists regarding students' own search for their identity in the midst of a new culture and how gradually that self-assurance translates into "acceptance" or adhering to their surroundings. McCarthy (1990) notes the difficulty that exists among the minority groups to adapt to their schools when they have not found a foundation for their own identity: "In terms of academic success and identity issues, one difficulty observed in minority students is the dilemma of striving to succeed and maintaining their own sense of who they are at the same time" (p.84). As immigrant Hispanic students find themselves situated in relation to their own sub-culture, they start demonstrating the capacity to undertake and focus on different and foreign scenarios such as the educational system (school) and that can in turn catapult the person into a main stream adherence of the dominant culture. The implications of this finding are many and not easily addressed. The educational system in the US aims at immersing the newly migrated students to an already established "model" which does little or nothing in helping the new students understand and cope with being part of a mixture of cultures under the big umbrella of the American Culture.

Despite not being supported, the rejected hypotheses do provide some relevant information on this complex issue. Neither GPA nor Number of years in the U.S. predicted immigrant students' a sense of belonging to the school system. Although not statistically significant, some of the positive trends found in this study point to the importance that exists between the variables of GPA and parents' number of years in the 
US. The correlation is as follows: The longer parents of immigrant Hispanic students have been in the U.S., the greater their GPA. This correlation speaks of the socialization and assimilation that exists among the immigrant students in regards to how, with time, they can move towards increasing their achievement in school. On the other hand, what this could indicate is the disadvantage these students have in relation to mainstream students. That is, it takes a good number of years for immigrant students to adapt to the new educational system before they can start to perform at an academically acceptable level. Immigrant Hispanic students' mean GPA and number of years in the US were 2.3 and 4.9 respectively. In regards to gender, neither boys or girls differed significantly on how long they have been in the U.S. nor do they differ significantly on their GPA.

In addition, regarding students' and parents' ethnic identity, a negative correlation was found. While this relationship was not statistically significant (perhaps due to sample size), the direction of the correlation suggest that the higher the students' orientation to other ethnic groups, the lower the parents' orientations to other ethnic groups relationships. Interestingly enough, another negative correlation was found in relation to hypothesis number 4 (students and parents' sense of school belonging). Again, while not significant, the direction of the correlation suggests that the higher the students' sense of school belongingness, the lower the parents' sense of connection to their child's school and belief about their child's connectedness to their school. Both of these negative correlations, I believe, speak of the reality that exists among immigrant families whose kids have recently migrated into this country at a young age in which they have not had time to discover who they really are, what they want, and what they wish to become in the future. These students find themselves in a foreign culture where they are expected to 
intermingle with many other cultures (Whites being the majority) and they are also expected to start performing academically the moment they put one foot in the school. The two areas that go largely ignored by the school system are the social and psychological aspects of making the transition from one culture to another. On the other hand, parents of immigrant Hispanic students do not face nearly as difficult scenarios than those of their children. To begin with, most of these parents have been in the U.S. for many years (eventually they brought the rest of the family to join them; wife and kids or just kids since many wives do come to the U.S. several years before the kids do). Parents are only supposed to perform at one level: provider for family (workforce). The great majority of Hispanic parents only know basic language skills (if any) to keep them in their jobs. Many of their jobs are in the fields or the food industry where they would have a bilingual manager and Spanish speaking co-workers by their sides on a daily basis. Many of these parents did little to no school in their country of origin and they did not grow up knowing or understanding their own educational system. These parents are by no means able to understand the American model of education. What this creates is a uni-lateral way of dealing with the schools: the kids are the ones in the system therefore they should be able to navigate it and keep "afloat." In a general sense, the negative correlations found in this study are trends that perhaps need individual attention since this could be an indicator of students and parents going opposite directions and thus creating disintegration in the families and a continuous rupture in the educational system as both groups (parents and students) look at the horizon through different sets of glasses and with different expectations. What could account for such different points of views from students and parents could be found in item number 7 from the Parents' Questionnaire: 
Do you want to go back to your country of origin? To this question, 26 (84\%) parents answered yes, $3(10 \%)$ answered no, and $2(6 \%)$ said they did not know. This allows one to see that while students are trying to adhere and be part of a new culture and having to face many difficulties and overcome obstacles, the overwhelming majority of parents, on the other hand, see themselves as "transients" in this culture. These parents could appear to have the luxury of not having to make the effort of being accepted by society in general and of having to perform accordingly and as expected by the educational system.

In regards to the qualitative results, it is important to start by noting that immigrant families have in the past and will continue to come to this country with a clear goal in mind: to better their lives in many respects with the foremost goal of being more financially stable. In the survey, $87 \%$ of the parents indicated they came to the U.S. with the intention of seeking a better life and future for themselves and their children. What remains to be asked is whether or not staying in the US permanently is part of their goal. By analyzing the responses to the questionnaires, it can be seen that a high percentage of immigrant families want or need their kids to work as soon as possible. In many cases that means working right out of high school (that is, if their kids do not drop out). It appears that immigrant parents see joining the work force as early as possible as the means by which families can survive and manage financially in this society. In the questionnaire, $63 \%$ of the parents indicated they saw their kids working right out of high school and $6 \%$ of the respondents indicated their kids would most likely attend a vocational school or program and then work. An aspect that was not explored in this study was the apparent sense of "urgency" from immigrant parents for their kids to work. 
Immigrant parents come to this country not knowing, understanding or trusting their own educational systems (from their own countries) and therefore, immigrant parents lack the connection needed to pass on to their kids the notion of the importance in obtaining an education. At first sight, it appears that immigrant parents are more concerned about the short-term goals than the long term benefits of their kids being able to finish a four-year education and that can be seen by only $12 \%$ of immigrant parents indicating in the survey they actually visualized their kids going and finishing a four-year career.

One relevant aspect worth pointing out is that $84 \%$ of parents expressed a desire or indicated they had plans to go back to their country of origin in the near future. Of the remaining respondents, $6 \%$ responded they were not sure and only $10 \%$ said they had no plans to go leave the U.S. What these numbers indicate is that for this sample of immigrant families living in San Luis Obispo with kids attending the local high school, these parents are perhaps not invested or interested in settling in and acquiring or being part a new culture but are rather in a state of "continuous transition." This means that while they are adjusting to being in a new country, these families continue to be in "movement" until they decide to get established in either this or another country. What remains to be studied is whether or not living in this particular county has a negative influence on immigrant families given the high cost of living, scarcity of low income housing and the community being predominantly White. In contrast, immigrant families living in the Santa Maria Area (Santa Barbara County) or in the north part of San Luis Obispo County might have a whole different experience of what it means to interact with mainstream Americans given that the Hispanic populations on those areas is significantly higher than in San Luis Obispo. 
What the majority of immigrant parents indicated as their main obstacle in living and working in this country was not being able to speak English (64\%). Parents also indicated the second biggest obstacle was dealing with their kids' behaviors (32\%). What these two single responses could represent is a struggle between parents and kids. The latter group is not likely to seek help from their parents when it comes to educational matters as their parents are not fluent or knowledgeable of the subjects their kids might need help with. In a similar way, parents are not likely to be as present or ready with their kids when it comes to educational matters since they, themselves, feel out of touch with what goes on in their kids' educational lives. The data that supports such statements could be found in the responses to questions 10, 12 and 16. The majority of immigrant parents indicated they were not informed about their kids' school (61\%). Furthermore, a significant number of parents responded they did not talk to their kids about school issues (48\%). Also $22 \%$ of parents responded they only talked to their kids some times about school issues. In regards to immigrant parents' attendance of school related activities and meetings, $58 \%$ indicated they never attend events that take place at school since they do not feel comfortable or understand what goes on during such meetings. Twenty six percent of parents attend meeting regularly and just $16 \%$ of them reported always attending school activities.

Another relevant aspect of the responses was the perception parents have of their kids' motivation to stay in school. More than half of the parents interviewed $(55 \%)$ perceived their kids as not motivated or wanting to continue with school. During the interview, parents indicated feeling pressure about not knowing how to talk to their kids about continuing with school and realized they could not provide direct assistance since 
in general they have no connection with the school or the teachers. Parents were also asked what their responses have been or would be should their kids decide they wanted to leave school. Thirty five percent said they did not know what they would do or say. Twenty six percent indicated they would be mad or sad. Nineteen percent said they would let their kids make whatever decision they wanted and another nineteen percent responded they would try to talk and encourage their kids to continue. Once we look at these numbers, it is significant to note that only $19 \%$ of parents take an active role in directing or influencing their kids' decisions regarding education. This illustrates a type of mentality from parents to leave their kids with the responsibility of managing their education and maneuvering around a foreign educational system. This isolation and lack of support from parents towards their kids is perhaps a clear factor that has to be considered when analyzing the high levels of dropouts.

Some parents commented they worry when their kids say they do not like school and want to quit. Parent's general notion is that they can (and some have) gotten in trouble with the school when their kids have missed days of school and when their children are failing academically. Parents argue they cannot afford to miss work to go to school and talk to teachers or counselors about their kids' not wanting to go to school or their kids' lack of achievement. This situation then gets transformed into a situation in which parents demand of their kids to continue to go to school and do well but the motivation is not necessarily so that kids can take advantage of their education but rather to avoid parents' being dragged to school (and miss work) and having to feel ashamed for what their kids are not doing well at school. In some instances, parents indicated they have clearly told their kids they need to start looking for a job if getting an education is 
not what their kids are interested in. One topic that requires further analysis is how much are immigrant students personally invested (internally) in finishing their high school education and how many of them consider the outside obstacles to be too many to deal with (external).

What might be speculated, and based on their responses, is that perhaps these parents do not see education as the "vehicle" that will get them or their children to achieve their desired goals (a better and more financially stable life).

What the data indicates is not so much that parents dislike school, but rather they lack a connection with the educational system in general. Moreover, it can be deduced that a great number of kids in this study are placed in the position of having to handle and manage their own educational process with minimal participation from parents. This is a great burden as kids are adapting to new culture and given too much responsibility.

\section{$\underline{\text { Limitations }}$}

One of the major limitations for this study was is sample size. A larger sample might have yielded more significant results in terms of how this particular study compared to other studies that utilized similar methods. The lower sample size of this study limited the statistical analyses utilized.

Another limitation found in this study is the lack of a comparative ethnic identity measure for parents (one with already established reliability and validity). Part of this study focused on the data provided by parents in relation to how they saw themselves in 
relation to other ethnic groups and it can not be concluded that their responses are "the voice" of all Hispanic parents given the limitations of the means in which this was measured with this sample of parents.

In relation to the interaction between parents and students, this study did not solicit feedback from students (open ended questions) regarding their thoughts on how they perceived their own parents involvement with the school in general or in their academic process. It would have been important to analyze how much do students feel their parents support them or not in their education and how much they are being left "alone" when it comes to school matters.

Another question this study did not ask students is how long they have been in the U.S. Some of the correlations in this study were based on Parents' number of years in the U.S. in relation to GPA or sense of belongingness to the school, but it would have been more appropriate to assess those same variables with the corresponding data (number of years in the U.S.) from the students.

One aspect this study missed was to gather more information on the students' and parents' experience of immigration. Parents and students could have provided direct feedback on how they see, rate, or evaluate their own immigration to this country in relation to how they used to live in their country of origin.

\section{$\underline{\text { Future Research }}$}

Part of the purpose of this study was to shed some light on future research that can help increase our understanding of the educational experiences of Hispanic immigrant students. Future research should include a larger sample size to increment the number of 
analyses that can be conducted and perhaps increase the possibility of detecting significant relationships. It will be important for future research to pay attention to equate both students' and parents' measures so that both can yield reliable and valid results. Qualitative data should be gathered from students to enrich future studies as they could provide very important information about their own immigration experiences and sense of connection they have with parents and the schools.

Another area that should be looked at in greater detail is gender differences. This study only touched on a few aspects regarding differences for males and females. Future research could yield specific differences and advantages or disadvantages boys and girls have in the arena of education, school connectedness, and ethnic identity.

\section{Implications}

Though there are clearly limits to this study, some of the positive trends found are aligned with previous research. For example, Phinney (1992), found no statistically significant differences between males and females on the MEIM of ethnic identity. However, high school females scored higher than males on various subscales of the MEIM (Phinney, 1992) which is similar to the findings of this study.

One more factor that has to be taken into account, and was not examined in this study, is how families see themselves in comparison to how they were doing in their country of origin. Let us remember that Latino or Hispanic families are being looked at and analyzed based on an "American model." To earn an income of $\$ 15,000$ per year, living in 2 bedroom apartment with 7 other people and having one family car for transportation are clearly signs of poverty in the U.S. What many fail to consider is that 
for a great number of families living under the circumstances described above is a step (or two or three) above what they used to experience when living back in their country of origin. The sense gathered from interviewing the families in this study and from working and relating with Hispanic families in different settings on a daily basis leaves me with the understanding that the underlining philosophy of the majority of Hispanic parents, which in turn is passed on to the kids, is that there is a need to work as early as possible to earn an income to provide for self and family and cover the immediate necessities and wants they long for. In consequence, delayed gratification and a vision for a solid and fruitful future (one based on education and a career) was rarely encountered among the families who participated in this study. Only $12 \%$ of parents stated they actually saw their kids graduating from a four-year university and working as professionals.

What seems to be happening is that parents and the educational system are not properly or completely geared to deal with each other so that each one can meet the other in the middle. From personal observations while conducting the parents' questionnaires, parents would express a sense of confusion in trying to navigate their kids' educational system. Parents would very often refer to the ESL teacher or the ESL teacher's aide as the only persons they have had contact with from their kids' high school. Often parents were not certain where the high school would be located at (physical address) and they would summon their kids to remind them or indicate to me (the interviewer) where they went to school. From the school's side, it is clear that they are trying to engage the parents of the immigrant Hispanic students but there are still a number of obstacles that have to be resolved such as language barriers and trying to have face to face contact with 
parents on occasions different than the meetings parents are called to based on their kids misbehaviors or lack of accomplishments.

\section{$\underline{\text { Conclusion }}$}

Schools need to be open to new ways of relating and communicating with the parents of immigrant Hispanic students. Schools need to take on a more pro-active role in educating the parents and making them feel more welcome to the schools. The school counselors could also supplement support and active participation parents are not demonstrating to students and guide and encourage them to thrive and move forward with their education. In sum, the schools could use some of the information presented in this study to elaborate an outreach program that will increase parents' participation in school and foster support for their kids and at the same time guidance and incentives for kids to continue to fully engage their educational experience.

In regards to the clinical application of the results provided in this study, one must understand that immigrant Hispanic students seeking psychological counseling will have more than one issue they need help with. Many of these students will feel misunderstood by parents, not trusting of teachers or the school in general and victims of a society that is not willing to accept them for who they are. The usual result of such frustrations could be seen in gang affiliation and a total rebellion against the main culture. Immigrant Hispanic teens will first start to challenge the "family-cell" and then transform their frustration into anger directed at that which they feel is against them. At some point, troubled teens see "disorder" as the new way of being and one they feel "right at home." At that moment, any entity trying to restore order will be seen as not in alignment with them. The 
challenge for therapists is to have the community resources needed to permit these kids to be connected back to the larger group and see and believe that they too can still be themselves and yet function as productive members of society. Often, poor academic performance will be the reason a teen will be referred to me, but underneath there are layers of unresolved issues ranging from anger towards parents to deep frustrations (depression) with themselves for being incapable of doing what is expected of them. Therapists' efforts aimed at understanding the importance of ethnic identity and sense of belongingness in their schools may help facilitate students' psychological sense of well being as well as have an impact on their overall academic success. 


\section{NOTES}

This study was successfully completed thanks to the time, effort and encouragement I received from Dr. Lisa Sweat to whom I am very grateful. 


\section{References}

Bernal, M. E., Saenz, D. S., \& Knight, G. P. (1991). Ethnic Identity and Adaptation of Mexican American Youth in School Settings. Hispanic Yournal of Behavioral Sciences, 13, 135-154.

Braddock, J. H., (1981). Race Athletics, and Educational Attainment: Dispelling the Myths. Youth and Society, 12, 335-350.

Brophy, J. (1983). Conceptualizing Student Motivation. Educational Psychologist, 18, 200-215.

Coates, J. (1986). Women, Men and Language: A Socio-linguistic Account of Sex Differences in Language. London: Longman.

Cooper, H., \& Burger, J. (1980). How teachers Explain Students' Academic Performance: A Categorization of Free Response Academic Attributions. Academic Educational Research Journal, 17, 95-109.

Courtney, P. D, Mesquita, B., P, \& Courtney, B. F. (1995). The potential Impact of PUSH: Changing Cognitive Attributions and Oppositional Identity Formations of Involuntary Minority High School Students. People and education, 3, 72-82.

Cummins, J. (1984). Bilingual and Special Education: Issues in Assessment and Pedagogy. San Diego: College Hill.

Davidson, A. L. (1996). Making and Molding Identity in Schools: Students Narratives on Race, Gender, and Academic Achievement. Albany, NY: SUNY Press.

De La Rosa, R. (1990). Hispanic Education: A statistical portrait. Washington, DC: National Council of La Raza. 
Delgado-Gaitan, C. (1988). The Value of Conformity: Learning to stay in School. Anthropology \& Education Quarterly, 19(4), 354-381.

Eugeene, M. (2000). At-risk youth: identification, programs, and recommendations. Englewood, Colo.: Teacher Ideas Press

Erickson, F. (1987). Transformation and School Success: The Politics and Culture of Education Achievement. Anthropology and Education Quarterly, 18(4),_335-356.

Fine, M. (1991). Framing Dropouts: Notes on the Politics of an Urban Public High School. Albany, NY: State University of New York Press.

Finn, C. (2004). Leaving no child behind?: options for kids in failing schools. New York: Palgrave Macmillan.

Flores-Gonzales (2002). School Kids/Street Kids: Identity Development in Latino Students. New York, New York: Teachers College Press

Flores-Gonzales, N. M. (1999). Puerto Rican High Achievers: An Example of Ethnic and Academic Identity Compatibility. Anthropology \& Education Quarterly, 30(3), 343-362.

Foley, D. E. (1991). Reconsidering Anthropological Explanations of ethnic School Failure. Anthropology \& Education Quarterly, 22(1), 60-94.

Fordham, S. (1988). Racelessness as a Factor in Black Students' School Success: Pragmatic Strategy or Pyrrhic Victory. Harvard educational review, 58(1), 54-84.

Gandara, P. (1995). Over the ivy Walls: The Educational Mobility of low Income Chicanos. Albany: State University of New York Press. 
Gonzales, Rosemary \& Padilla, M. Amado (1997). The Academic Resilience of Mexican American high School Students. Hispanic Journal of behavioral Sciences, 19(3), 301-317.

Goodenow, C. (1992). School Motivation, Engagement, and a Sense of Belonging Among Urban Adolescent Students. New York: Sunny Press.

Goodenow, C. (1993). The psychological sense of school membership among adolescents: Scale development and educational correlates. Psychology in the Schools, 30, 79-90.

Graham, S. (1986). An Attributional Perspective on Achievement Motivation and Black Children. In Feldman (Ed.), Social Psychology Applied to Education (pp. 39-65). New York: Cambridge University Press.

Gramsci, A. (1971). Selections from Prison Notebooks. New York: International Publishers.

Grant, Linda (1984). Black females "place” in desegregated classrooms. Sociology of Education, 57, 98-111.

Grant, Linda (1985). Uneasy alliances: Black males, teachers, and peers in desegregated classrooms. New York, DC: McGraw-Hill

Grebler, L., Moore, J. W., \& Guzman, R. C. (1970). The Mexican American People. New York: The Free Press.

Hamann, E. T., Wortham, S., \& Murillo, E. G. (2002). Education and Policy in the New Latino Diaspora. Westport, Connecticut: Ablex Publishing.

Hechinger, F. M. (1992). Fateful Choices: Healthy youth for the $21^{\text {st }}$ century. New York: Carnegie Corporation. 
Hemmings, A. (1996). Conflicting Images? Being black and a Model High School Student. Anthropology \& Education Quarterly, 27(1), 20-50.

Kozol, J. (1985). Illiterate America. New York: Doubleday Anchor.

Kukla, A. (1972). Attributional Determinants of Achievement-related Behavior. Journal of Personality and Social Psychology, 21, 166-174.

Lareau, A. (1989). Home Advantage: Social Class and Parental Intervention in Elementary Education. Philadelphia, PA: Falmer.

Losey, M. Kay (1997). Listen to the Silences: Mexican American Interaction in the Composition Classroom and the Community. Norwood, New Jersey: Ablex Publishing Corp.

Macedo, D. (1997). English Only: The Tongue-trying of America. In Darder, Torres, \& Gutierrez (Eds.), Latinos and Education: A Critical reader_(pp. 269-278). New York: Routledge

McCarthy, Cameron (1990). Multicultural education, minorities, textbooks, and the challenge of curriculum reform. Journal of Education, 172(2),_118-130.

McGowan, R. P. \& Johnson, D. L. (1984). The Mother Child Relationship and other Antecedents of Academic Performance: A Causal Analysis. Hispanic Journal of Behavioral Sciences, 6, 205-224.

McLaren, P. L. (1994). Life in Schools. New York: Longman.

Mier, J. K., Stewart, J. (1991). The Politics of Hispanic Education: Un Paso pa'lante y dos pa'tras. Albany, New York: State University of New York Press.

Moran, J. J., Yengo, L., \& Alguier, A. M. (1994). Participation in Minority Oriented Cocurricular Organizations. Journal of College Student Development, 35, 143. 
Newmann, F. H., Wehlage, G. G., \& Lamborn, S. D. (1992). The significance and Sources of Student Engagement. In Newmann (Ed.), Student Engagement and Achievement in Secondary Schools (pp. 11-39). New York: Teachers College Press.

Ogbu, J. U. (1978). Minority Education and Caste: The American System in Cross-Cultural Perspective. New York: Auburn House

Oliver, H. (1995). Influence on Motivational Factors on Performance. Journal of Instructional Psychology, 22, 45-49.

Ortiz, F. I. (1988). Hispanic American Children's Experiences in classrooms: A Comparison Between Hispanic and non-Hispanic Children. In Weis (Ed.), Class, Race, and Gender in American Education (pp. 63-86). New York: State University of New York Press.

Phelan, P., Davidson, A. L., \& Yu, C. H. (1998). Adolescents' Worlds: Negotiating Family, Peers, and School. New York: Teachers College Press.

Phinney, J. S. (1992). The multigroup ethnic identity measure: A new scale for use with diverse groups. Journal of Adolescence Research, 7(2), 156-176.

Pugach, Marleen C. (1998). On the Border of Opportunity: Education, Community, and Language at the U.S.-Mexico Line. Mahwah, NJ: Lawrance Erlbaum Associates.

Purkey, S. C., \& Smith, M. S. (1983). Effective Schools: A review. The Elementary School Journal, 83, 428-452.

Rendon, Laura, I., (2003). Foreword: The Majority in the Minority. Sterling, Virginia: Stylus

Riessman, Frank (1962). The Culturally Deprived Child. New York: Style Press 
Rosenthal, R. \& Jacobson, L. (1968). Pygmalion in the Classroom: Teacher Expectations and Pupils' intellectual development. New York: Holt, Rinehart and Winston.

Rumbaut, R. and Cornelius, W. (1995). California's immigrant children: theory, research, and implications for educational policy. San Diego, California: Center for U.S.Mexican Studies, University of California, San Diego.

Rumberguer, R. (1995). Chartering Urban School Reform. New York: Teachers College Press

Ruiz, Richard (1997). The Empowerment of Language-Minority Students. In Darder, Torres, \& Gutierrez (Eds.), Latinos and Education: A Critical Reader (pp. 319328). New York, New York: Routledge

Scriber, J, Young, M. D., \& Pedroza, A. (1999). Building Collaborative Relationships with Parents. In Reyes, Scribner, \& Scribner (Eds.), Lessons From High Performing Hispanic Schools (pp. 36-60). New York: Teachers College Press.

Shannon, S. M. (1996). Minority Parental Involvement; A Mexican Mother's Experience and a Teacher's Interpretation. Education and Urban Society, 29(1), 71-84. Suarez-Orozco, Marcelo (1989). Central American Refugees and U.S. High Schools: A Psychological Study of Motivation and Achievement. Stanford, California: Stanford University Press.

Valdes, Guadalupe (1996). Con Respeto: Bridging the Distances Between Culturally Diverse Families and schools, an Ethnographic Portrait. New York: Teachers College Press. 
Valenzuela, A. (1999). Substractive Schooling: U.S.-Mexican Youth and the Politics of Caring. Albany, NY: Sunny Press.

Viadero, D. (1989). Schools witness a troubling revival of bigotry. New York: State University of New York Press.

Waggoner, D. (1991). Under Education In America: The Demography of High School Dropouts. New York: Auburn House

Wehlage, Gary G. (1989). Dropping Out: Can Schools be Expected to Prevent it? In Weis, Farrar, \& Petrie (Eds.), Dropouts From Schools: Issues, Dilemmas and Solutions (pp. 1-19). New York: State University of New York Press.

Weiner, B. (1985). An Attributional Theory of Achievement Motivation and Emotion. Psychology Review, 92, 548-573.

Weiner, B., Frieze, I., Kukla, A., Reed, L., Rest, S., \& Rosenbaum, R. M. (1971). Perceiving the Causes of Success and Failure. In Jones, Kanouse, Kelley, Nisbett, Valins, \& Weiner (Eds.), Attribution: Perceiving the Causes of Behavior (pp. 95-120). Morristown, NJ: General Learning Press.

Weinstein, R. S. (1986). The Teaching of reading and Children's Awareness of Teacher Expectations. In Raphael (Ed.), The Context of School Based Literacy (pp. 233252). New York: Random House.

Wilson, B. L., \& Corcoran, T. B. (1988). Successful Secondary schools. New York: Falmer Press.

Zill, N. (1995). Adolescence adolescent Time Use, Risky Behaviors and Outcomes. Washington DC: Public Health Service. 
Appendix A

The Multigroup Ethnic Identity Measure (English)

\section{The Multigroup Ethnic Identity Measure}

In this country, people come from a lot of different cultures and there are many different words to. describe the different backgrounds or ethnic groups that people come from. Some examples of the names of ethnic groups are Mexican-American, Hispanic, Black, Asian American, American, Indian, Anglo-American, and White. Every person is born into an ethnic group, or sometimes two groups, but people differ on how important their ethnicity is to them, how they feel about it, and how much their behavior is affected by it. These questions are about your ethnicity or your ethnic group and how you feel about it or react to it.

Please fill in:

In terms of ethnic group, I consider myself to be

Use the numbers given below to indicate how much you agree or disagree with each statement.

1: Strongly disagree $\quad 2:$ Somehow disagree

3: Somewhat agree $\quad$ 4: Strongly agree

\section{I have spent time trying to find out more about my own ethnic group, such as its} history, traditions, and customs.

$\begin{array}{llll}1 & 2 & 3 & 4\end{array}$


2. I am active in organizations or social groups that include mostly members of my own ethnic group.

$\begin{array}{llll}1 & 2 & 3 & 4\end{array}$

3. I have a clear sense of my ethnic background and what it means to me.

$1 \quad 2 \quad 3 \quad 4$

4. I like meeting and getting to know people from ethnic groups other than my own.

$1 \quad 2 \quad 3 \quad 4$

5. I think a lot about how my life will be affected by my ethnic group membership.

$1 \quad 2 \quad 3 \quad 4$

6. I am happy that I am a member of the group I belong to.

$1 \quad 2 \quad 3 \quad 4$

7. I sometimes feel it would be better if different ethnic groups didn't try to mix together.

$\begin{array}{llll}1 & 2 & 3 & 4\end{array}$

8. I am not clear about the role of my ethnicity in my life.

$\begin{array}{llll}1 & 2 & 3 & 4\end{array}$

9. I often spend time with people from ethnic groups other than my own.

$1 \quad 2 \quad 3 \quad 4$

10. I really have not spent much time trying to learn more about the culture and history of my ethnic group.

$\begin{array}{llll}1 & 2 & 3 & 4\end{array}$


11. I have a strong sense of belonging to my own ethnic group.

$1 \quad 2 \quad 3 \quad 4$

12. I understand pretty well what my ethnic group membership means to me, in terms of how to relate to my own group and other groups.

$1 \quad 2 \quad 3 \quad 4$

13. In order to learn more about my ethnic background, I have often talked to other people about my ethnic group.

$\begin{array}{llll}1 & 2 & 3 & 4\end{array}$

14. I have a lot of pride in my ethnic group and its accomplishments.

$1 \quad 2 \quad 3 \quad 4$

15. I don't try to become friends with people from other ethnic groups.

$1 \quad 2 \quad 3 \quad 4$

16. I participate in cultural practices of my own group, such as special food, music, or customs.

$\begin{array}{llll}1 & 2 & 3 & 4\end{array}$

17. I am involved in activities with people from other ethnic groups.

$1 \quad 2 \quad 3 \quad 4$

18. I feel a strong attachment towards my own ethnic group.

$\begin{array}{llll}1 & 2 & 3 & 4\end{array}$

19. I enjoy being around people from ethnic groups other than my own.

$\begin{array}{llll}1 & 2 & 3 & 4\end{array}$

20. I feel good about my cultural or ethnic background.

$\begin{array}{llll}1 & 2 & 3 & 4\end{array}$


Write in the number that gives the best answer to each question.

\section{My ethnicity is}

(1) Asian, Asian American, or Oriental (2) Black or African American

(3) Hispanic or Latino

(4) White, Caucasian, European, not Hispanic (5) American Indian

(6) Mixed; parents are from two different groups

(7) Other (write in):

22. My father's ethnicity is (use numbers above)

23. My mother's ethnicity is (use numbers above) 
Appendix B

The Multigroup Ethnic Identity Measure (Spanish)

\section{La Medida de Identidad de MultigruposEtnicos}

En este país, la gente viene de diferente culturas y hay diferentes palabras para describir los diferentes modos de culturas o grupos étnicos de donde vienen sus orígenes. Algunos ejemplos de nombres de grupos étnicos son Mexicanos-Americanos, Hispanos, Negros, Asiáticos-Americanos, Anglo-Americanos, y Blancos. Cada persona nacida dentro de un grupo étnico, o algunas veces en dos grupos, difiere en como importante es su etnicidad para ellos, como ellos se sienten acerca de ello y como sus comportamientos es afectado por eso. Estas preguntas son acerca su etnicidad 0 su grupo étnico y como se siente 0 como reacciona de ello.

Favor de llenar las formas:

En términos de grupo étnico, yo me considero:

Use los números que se encuentran abajo para contestar cada pregunta, ya sea que este de acuerdo o en desacuerdo.

1. No estoy de acuerdo $\quad 2$ Algunas veces de acuerdo

3. Algo de acuerdo 4. Muy de acuerdo

1. He dedicado algo de tiempo para saber mas acerca de mi grupo étnico, como la historia, tradiciones y costumbres.

$\begin{array}{llll}1 & 2 & 3 & 4\end{array}$


2. Soy activo en organizaciones 0 grupos sociales en los cuales la mayoría de sus miembros son de mi propio grupo étnico.

$1 \quad 2 \quad 3 \quad 4$

3. Tengo un sentimiento claro de mi grupo étnico y 10 que significa para mi.

$\begin{array}{llll}1 & 2 & 3 & 4\end{array}$

4. Me gusta conocer y tratar a otra gente de otras grupos étnicos.

$1 \quad 2 \quad 3 \quad 4$

5. Pienso demasiado en como va a influir en mi vida el grupo étnico al que pertenezco.

$\begin{array}{llll}1 & 2 & 3 & 4\end{array}$

6. Soy feliz por ser miembro del grupo étnico al que pertenezco.

$1 \quad 2 \quad 3 \quad 4$

7. Siento que todo seria mejor si diferentes grupos étnicos no se mezclaran entre si.

$\begin{array}{llll}1 & 2 & 3 & 4\end{array}$

8. No es muy claro el papel que desempeña mi etnicidad en mi vida.

$\begin{array}{llll}1 & 2 & 3 & 4\end{array}$

9. Normalmente paso tiempo con gente de otras grupos étnicos.

$\begin{array}{llll}1 & 2 & 3 & 4\end{array}$

10. En verdad no he dedicado mucho tiempo para aprender mas en cuanto a la historia y cultura de mi grupo étnico.

$\begin{array}{llll}1 & 2 & 3 & 4\end{array}$

11. Siento fuertemente que pertenezco a mi grupo étnico.

$\begin{array}{llll}1 & 2 & 3 & 4\end{array}$


12. Yo se 10 que significa pertenecer ami propio grupo étnico, en 10 que respecta a saber como relacionarme con el mismo y otras.

$1 \quad 2 \quad 3 \quad 4$

13.' Para poder aprender mas acerca de mi raíces, normalmente hablo con otras acerca de mi grupo étnico.

$1 \quad 2 \quad 3 \quad 4$

14. Estoy orgulloso(a) de mi grupo étnico y sus logras.

$\begin{array}{llll}1 & 2 & 3 & 4\end{array}$

15. No trato de ser amigo(a) de otras grupos étnicos.

$\begin{array}{llll}1 & 2 & 3 & 4\end{array}$

16. Participo en actividades culturales de mi propio grupo étnico, por ejemplo, comidas especiales, música y costumbres.

$\begin{array}{llll}1 & 2 & 3 & 4\end{array}$

17. Estoy involucrado(a) en actividades con gente de otras grupos étnicos.

$1 \quad 2 \quad 3 \quad 4$

18. Siento un gran afecto por mi grupo étnico.

$\begin{array}{llll}1 & 2 & 3 & 4\end{array}$

19. Disfruto estar con gente de otros grupos étnicos.

$\begin{array}{llll}1 & 2 & 3 & 4\end{array}$

20. Me siento a gusto en cuanto a mi antecedente cultural y étnico.

$\begin{array}{llll}1 & 2 & 3 & 4\end{array}$

21. Mi etnicidad es 
1. Asiático(a), Asiático(a)-Americano(a), o Oriental

2. Negra(a) o Afra(a)-Americano(a)

3. Hispano(a) o Latino(a)

4. Europeo(a), Caucáseo(a), Blanco(a) [No Hispano(a)]

5. Indio(a)-Americano(a)

6. Mexicano(a)

7. Mexicano(a) - Americano(a)

8. Mixto(a); mis padres son de dos diferentes grupos étnicos

9. Otro: (escríbalo)

22. EI grupo étnico de mi padre es (use los números de arriba para contestar esta pregunta.)

23. EJ grupo étnico de mi madre es (use los números de arriba para contestar esta pregunta.) 
Appendix $\mathrm{C}$

The Psychological Sense of School Membership (English)

\section{Psychological Sense of School Membership}

The following questions are about you general opinion of San Luis Obispo High school.

Please circle the number that best describes how you really feel toward the school and what you think about school in general in relation to your teachers and other students.

$\begin{array}{ll}\text { 1: Not al all True } & \text { 2: Mostly False } \quad \text { 3: Sometimes True } \\ \text { 4: Mostly True } & \text { 5: Completely True }\end{array}$

Please respond truthfully to the following questions:

\section{I feel like a real part of San Luis Obispo High School}

$\begin{array}{lllll}1 & 2 & 3 & 4 & 5\end{array}$

2. People here notice when I am good at something

$\begin{array}{lllll}1 & 2 & 3 & 4 & 5\end{array}$

3. It is hard for people like me to be accepted here

$\begin{array}{lllll}1 & 2 & 3 & 4 & 5\end{array}$

4. Other students in this school take my opinions seriously

$\begin{array}{lllll}1 & 2 & 3 & 4 & 5\end{array}$

5: Most teachers at San Luis Obispo High school are interested in me

$\begin{array}{lllll}1 & 2 & 3 & 4 & 5\end{array}$


6. Sometimes I feel as if I don't belong here

$\begin{array}{lllll}1 & 2 & 3 & 4 & 5\end{array}$

7. There is at least one teacher or adult in this school I can talk to if I have a problem

$\begin{array}{lllll}1 & 2 & 3 & 4 & 5\end{array}$

8. People at this school are friendly to me

$\begin{array}{lllll}1 & 2 & 3 & 4 & 5\end{array}$

9. Teachers here are not interested in people like me

$\begin{array}{lllll}1 & 2 & 3 & 4 & 5\end{array}$

10. I am included in lots of activities at San Luis Obispo High School

$\begin{array}{lllll}1 & 2 & 3 & 4 & 5\end{array}$

11. I am treated with as much respect as other students•

$\begin{array}{lllll}1 & 2 & 3 & 4 & 5\end{array}$

12. I feel very different from most other students

$\begin{array}{lllll}1 & 2 & 3 & 4 & 5\end{array}$

13 I can really be myself at this school,

$\begin{array}{lllll}1 & 2 & 3 & 4 & 5\end{array}$

14. The teachers here respect me

$\begin{array}{lllll}1 & 2 & 3 & 4 & 5\end{array}$

15. People here know I can do good work

$\begin{array}{lllll}1 & 2 & 3 & 4 & 5\end{array}$

16. I wish I were in a different school

$\begin{array}{lllll}1 & 2 & 3 & 4 & 5\end{array}$


17. I feel proud of belonging to San Luis Obispo High School

$\begin{array}{lllll}1 & 2 & 3 & 4 & 5\end{array}$

18. Other students here like me the way I am

$\begin{array}{lllll}1 & 2 & 3 & 4 & 5\end{array}$


Appendix D

The Psychological Sense of School Membership (Spanish)

\section{PsychologicalSenseofSchoolMembership -Español}

Las siguientes preguntas tienen que ver con su opinión general sobre San Luis Obispo HighSchool. Encierre en un circulo 10 que se acerca mas a 10 que realmente siente sobre la escuela en general y 10 que piensa sobre todas sus clases, maestros(as) y otros estudiantes.

\section{Completamente Falso 2. A veces Falso 3. A veces Cierto}

\section{Casi siempre Cierto 5. Completamente Cierto}

Por favor responda honestamente a las siguientes preguntas:
1. Siento que soy parte de San Luis Obispo HighSchool
$\begin{array}{lllll}1 & 2 & 3 & 4 & 5\end{array}$
2. Las personas de la escuela se dan cuenta si soy
$\begin{array}{lllll}1 & 2 & 3 & 4 & 5\end{array}$ bueno(a) en algo
3. Es difícil que la gente como yo sea aceptada aquí
$\begin{array}{lllll}1 & 2 & 3 & 4 & 5\end{array}$
4. Otros estudiantes en esta escuela toman mi opinión
$\begin{array}{lllll}1 & 2 & 3 & 4 & 5\end{array}$ en serio

5. La mayoría de los maestros se interesan par mi

$\begin{array}{lllll}1 & 2 & 3 & 4 & 5\end{array}$

6. A veces siento que no pertenezco a esta escuela

$\begin{array}{lllll}1 & 2 & 3 & 4 & 5\end{array}$

7. Por lo menos hay un maestro( a) o adulto con quien

$\begin{array}{lllll}1 & 2 & 3 & 4 & 5\end{array}$ puedo hablar si tuviera un problema
8. La gente de esta escuela es amistosa conmigo
$\begin{array}{lllll}1 & 2 & 3 & 4 & 5\end{array}$
9. Los maestros(as) no se interesan en gente como yo
$\begin{array}{lllll}1 & 2 & 3 & 4 & 5\end{array}$ 
10. Me incluyen en muchas actividades en esta escuela

$\begin{array}{lllll}1 & 2 & 3 & 4 & 5\end{array}$

11. Me tratan con el mismo respeto que a los otros estudiantes $\begin{array}{lllll}1 & 2 & 3 & 4\end{array}$

12. Me siento my diferente de la mayoría de los

$\begin{array}{lllll}1 & 2 & 3 & 4 & 5\end{array}$ estudiantes de aquí

13. Realmente puedo ser "yo mismo( a)" en esta escuela $\quad \begin{array}{lllll}1 & 2 & 3 & 4\end{array}$

14. Los maestros(as) me respetan $\quad \begin{array}{lllll}1 & 2 & 3 & 4 & 5\end{array}$

15. La gente de aquí f sabe que puedo hacer un buen trabajo $\begin{array}{llllll}1 & 2 & 3 & 4\end{array}$

16. Yo quisiera estar en una escuela diferente $\quad \begin{array}{lllll}1 & 2 & 3 & 4\end{array}$

17. Estoy orgulloso(a) de pertenecer a esta escuela $\quad \begin{array}{lllll}1 & 2 & 3 & 4\end{array}$

18. A los otros estudiantes les gusta como yo soy $\quad \begin{array}{lllll}1 & 2 & 3 & 4\end{array}$ 
Appendix E

Parents' Questionnaire (English)

\section{Interview Questions for Parents of Immigrant Hispanic Students}

GPA:

1. How many of your children are going to High School?

2. How many children do you have?

3. Grade of your High School teen(s) Age:

4. How long have you lived in the U.S.?

5. What is your motivation for living in the U.S.?

6. How many jobs do you have? Hours worked per week?

7. Do you plan to go back to your country of origin?

8. What do you find most difficult about living and raising children in the U.S.?

9. What would your son/daughter like to be/do/study in the future?

10. How informed are you of your son/daughter's school?

11. Do you think your son/daughter feels he/she belongs to his/her school?

12. How often do you talk to your children about school?

13. What is your son/daughter's strong/less-liked subjects?

14. Do you think your son/daughter is understood and respected by his/her teachers?

15. What educational qualities/weakness do you see in your son/daughter?

16. How often do you attend school related activities?

17. Do you believe your son/daughter is able to be who he/she "is" at school? 
18. How do you see your son/daughter in five years from now?

19. Has your son/daughter told you he/she did not want to go to school anymore? What was your reaction?

20. If your son/daughter expressed he/she did not want to go to school anymore, what would your reaction be?

21. what does your children do after school?

22. what does your son/daughter think about his/her education and school in general?

23. Do you believe your son/daughter will finish high school and successfully graduate from a four year university? Please explain your answer.

24. Does your son/daughter have friends? Their names?

25. Does your son/daughter relate to teens from other ethnic groups?

26. How much importance do you give your son/daughter's opinions about school? Any reasons for that?

27. Do you as a parent have any social interaction with people from other ethnic groups?

28. Would you as a parent or encourage your son/daughter to relate to teens from other ethnic groups? 
Appendix F

Parents' Questionnaire (Spanish)

\section{Preguntas para los Padres de Estudiantes Imigrantes Hispanos}

GPA

1. Cuantos de sus hijos atienden la preparatoria?

2. Cuantos hijos tiene usted en total?

3. En que ano van sus hijo(a)? Edad

4. Cuanto tiempo lleva viviendo en los Estados Unidos?

5. Cual es su motivación al vivir en los Estados Unidos?

6. Cuantos trabajos tiene usted? Cuantas horas trabaja a la semana?

7. Piensa usted regresar a su país de origen?

8. Que es lo que usted considera mas difícil sobre el vivir en esta país y el criar a sus hijos?

9. Que es lo que usted cree que su hijo/a quiere ser/hacer/estudiar en el futuro?

10. Que tan informado esta usted sobre la escuela de su hijo/a

11. Cree que su hijo/a se siente parte de la escuela a la que pertenece?

12. Que tan seguido platica usted con su hijo/a sobre temas escolares?

13. Cual es la materia favorita o menos favorita de su hijo/a?

14. Piensa usted que su hijo/a es entendido o respetado por sus maestros?

15. Cuales cualidades o debilidades académicas observa usted en su hijo/a?

16. Que tan seguido atiende usted actividades escolares? 
17. cree usted que su hijo/a es libre de ser quien el/ella "es" en la escuela a la que pertenece?

18. Como se imagina usted a su hijo/a en cinco anos?

19. Le ha comentado su hijo/a que quiere dejar de estudiar? Cual fue su reacción?

20. Si su hijo/a le informara el/ella ya no quiere estudiar, cual seria su reaccion?

21. Que hacen sus hijos después de la escuela?

22. Que piensan sus hijos sobre la escuela y la educación en general?

23. Considera usted que su hijo/a podrá terminar la highschool y completar una carrera universitaria? Por favor explique sus razones.

24. Sus hijos tienen amigos? Sabe sus nombres?

25. Sus hijos se relacionan con jóvenes de otros grupos étnicos?

26. Que tan enserio toma usted las opiniones de sus hijos? En que se basa?

27. Ustedes como padres tienen rose social con gente de otras culturas o grupos étnicos?

28. Con relación a sus hijos, aceptan ustedes como padres el que se mezclen diferentes grupos étnicos? 
Appendix G

Youth Consent Form (English)

\section{Consent form for minors}

Francisco B. Ortiz in the Psychology and Child Development department of Cal Poly, San Luis Obispo is performing a project about school environment and academic performance. The purpose of this study is to try to understand the way Hispanic students think and feel regarding school, teachers, and their academic aspirations for the future.

Your son/daughter is being invited to participate in this study by answering two small questionnaires, which will take approximately 15 minutes to complete. Please remember that your son/daughter is not obligated to participate in this study and that they may choose to discontinue themselves from participating at any time during the process and that there will not be any penalties for them. If they so decide, they may choose not to answer any questions they do feel comfortable with.

There are no risks associated with your son/daughter's participation in this study. In the event they may feel uncomfortable with the procedures of this study, they can contact Mrs. Delkescamp, in the San Luis Obispo High School's main office at 596-4048.

Your son/daughter's answers will be kept anonymous to prevent their privacy. Some benefits associated with their participation in this study include knowing that their 
participation and comments provided could help faculty and staff better understand Hispanic students' experiences with the educational system and that future groups of students will be assisted in better ways regarding their educational needs.

If you have any questions regarding this study or would like to be informed of the results upon the completion of it, please contact my supervisor, Dr. Lisa Sweatt at 756-6123. If you have any other question in regards to the way this study was conducted, you can contact Steve Davis, Chair committee of Human Subjects at Cal Poly at 756-2754, or Susan Opava, Dean of Research and Post Graduate Programs at 756-1580.

If you consent your son/daughter's participation in this study as it is stipulated, please sign below. A copy of this form will be sent to you with your son/daughter.

Name of student

Signature of parent/guardian 
Appendix $\mathrm{H}$

Youth Consent Form (Spanish)

\section{Forma de Consentimiento para la Participación de Menores}

Un proyecto de investigación sobre el ambiente escolar y el aprovechamiento académico esta siendo conducido por Francisco B. Ortiz en el Departamento de Psicología y Desarrollo Infantil en Cal Poly, San Luis Obispo. El propósito del estudio es entender los pensamientos y sentimientos de los estudiantes Hispanos acerca de la escuela, los maestros, y sus aspiraciones educativas para el futuro.

La participación de su hijo(a) esta siendo solicitada para que complete un cuestionario. Este tomara aproximadamente 15 minutos. Por favor, debe de recordar que de ninguna manera su hijo(a) tiene la obligación de participar en este estudio y que ellos pueden dejar de participar en cualquier momento sin que haya alguna sanción hacia ellos. Si así 10 desean, pueden dejar cualquier pregunta del cuestionario sin contestar.

No hay ningún riesgo asociado con la participación de sus hijos en este estudio. Si de alguna manera se sienten incómodos con el procedimiento de este estudio, ellos pueden contactar a la prefecta de estudiantes, Rita Delkescamp, en la oficina principal para que se les preste ayuda. 
Las respuestas de sus hijos serán mantenidas anónimas para proteger su privacidad. Algunos beneficios asociados con este estudio incluyen el beneficio de saber que la participación y comentarios en este proyectopodrán ayudar a los maestros y al personal docente de la institución a entender de una mejor manera las experiencias educativas de sus hijos y a lograr que futuros grupos de estudiantes Hispanos puedan ser asistidos de una mejor manera con sus necesidades educativas.

Si tiene alguna pregunta con respecto a este estudio 0 quiere ser informado de los resultados cuando el estudio este completado, por favor póngase en contacto con mi supervisora, Dr. Lisa Sweeatt at 756-6123. Si tiene alguna pregunta opreocupación en respecto a la manera en la que este estudio se administro, puedes contactar a Steve Davis, Silla del Comité de Estudios Humanos de Cal Poly, al 756-2754, o Susan Opava, prefecta de Investigación y de Programas Post-Grado al 756-1508.

Si esta deacuerdo a que su hijo( a) participe voluntariamente en este estudio tal y como esta estipulado, por favor indique su consentimiento con su firma abajo. Una copia de esta forma de consentimiento será mandada a usted con su hijo(a)

Nombre del Estudiante

Firma del Padre/Guardián 


\section{Appendix I}

$\underline{\text { Parent Consent Form (English) }}$

\section{InformConcentForm (Parents)}

Francisco B. Oliiz in thePsychologyandChildDevelopmentdepmimentof Cal Poly, San Luis Obispo isperforming a projectofinvestigationaboutschoolenvironmentandacademic performance.

ThepurposeofthisstudyistotrytounderstandthewayHispanicstudentsthinkandfeelregardings chool, teachers, andtheiracademicaspirationsforthefuture. Moreover, thisstudywilltrytounderstandthewayparentsfeelandthinkregardingwhatittakesforthemtorais echildren in the U.S. andtheirunderstandingoftheirchildren'seducationalexperiences in this country.

You are beinginvitedtoparticipate in thisstudy by answeringsomequestionsandconduct a personal interviewwiththeresearcher. Yourparticipationwilltakeapproximately 20-30 minutes. Pleaserememberthatyou are notobligatedtoparticipate in thisstudyandthatyou may choosetodiscontinueyourselffromparticipating at any time duringtheinterviewprocessantthattherewillnot be anypenaltiestoyou. Ifyou so decide, you may decide nottoansweranyquestionbeingasked by theinterviewer. 
There are no risksassociatedwithyourpmiicipation in thisstudy. In theeventyou may feeluncomfortablewiththeproceduresofthisstudy, pleasecontactMrs. Delkescamp,in' the San Luis Obispo HighSchool'smain office at 596-4048.

Youranswerswill be keptanonymoustopreventyourprivacy.

Somebenefitsassociatedwithyourparticipation in

thisstudyincludeknowingthatyourparticipationandcommentsprovidedcouldhelpfacultyand staff betterunderstandHispanicstudents'

experienceswiththeeducationalsystemandthatfuturegroupsofstudentswill be assisted in betterwaysregardingtheireducationalneeds.

Ifyouhaveanyquestionsregardingthisstudyorwouldliketo be informedoftheresultsuponthecompletionofit, pleasecontact my supervisor, Dr. Lisa Sweatt at 756-6123. Ifyouhaveanyotherquestion in regardstothewaythisstudywasconducted, you can contact Steve Davis, Chaircommitteeof Human Subjects at Cal Poly at 756-2754, or Susan Opava, Dean ofResearchand Post GraduatePrograms at 756-1580.

Ifyouagreetoparticipate in thisstudy as itisstipulated, pleaseindicateyourconsentverballytotheinterviewer. Pleasekeepthisformforyourrecords. 
Appendix $\mathbf{J}$

$\underline{\text { Parent Consent Form (Spanish) }}$

\section{Forma de Consentimiento (Padres)}

Un proyecto de investigación sobre el ambiente escolar y e1 aprovechamiento académico esta siendo conducido por Francisco B. Ortiz en el Departamento de Psicología y Desarrollo Infanti1 en Cal Poly, San Luis Obispo. El propósito del estudio es entender los pensamientos y sentimientos de los estudiantes Hispanos acerca de la escuela, los maestros, y sus aspiraciones educativas para el futuro. Además, este estudio tratara de entender los pensamientos y sentimientos de los padres de los estudiantes con respecto a 10 que envuelve el criar niños en los Estados Unidos y su entendimiento acerca de la experiencia educativa de sus hijos en este país.

Se esta solicitando su participación en este estudio que se llevara acabo de manera directa por medio de una entrevista personal. Su participación tomara aproximadamente 20-30 minutos. Por favor, recuerde que de ninguna manera tiene la obligación de participar en este estudio y que puede dejar de participar en cualquier momento sin que haya alguna sanción hacia usted. Si así 10 desea, puede dejar cualquier pregunta del cuestionario sin contestar.

No hay ningún riesgo asociado con su participación en este estudio. Si de alguna manera se siente incomodo(a) con el procedimiento de este estudio, usted puedes contactar a la 
prefecta de estudiantes, Rita Delkescamp, en la oficina principal de la Preparatoria de San Luis Obispo al teléfono 596-4048 para que le asista.

Sus respuestas serán mantenidas anónimas para proteger su privacidad. Algunos beneficios asociados con este estudio incluyen el saber que su participación y comentarios en este proyecto podrán ayudar a los maestros y personal docente entender de una mejor manera sus experiencias con el sistema educativo y que los futuros grupos de estudiantes Hispanos podrán ser asistidos de una mejor manera con sus necesidades educativas.

Si tiene alguna pregunta con respecto a este estudio o quiere ser informado de los resultados cuando el estudio este completado, favor de contactar ami supervisora, Dr. Lisa Sweeatt at 756-6123. Si tiene alguna pregunta o preocupación con respecto ala manera en que se administro este estudio, puede contactar a Steve Davis, Silla del Comité de Estudios Humanos de Cal Poly, al 756-2754, o Susan Opava, prefecta de Investigación y de Programas Post-Grado al 756-1508.

Si estas deacuerdo a participar en este estudio de investigación tal como se estipula, por favor indica tu consentimiento verbalmente con el entrevistador. Por favor guarda esta forma de consentimiento para tus archivos. 


\section{Appendix K}

\section{Human Subject Committee Approval}

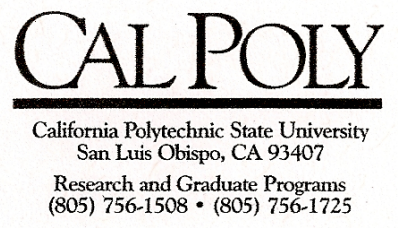

June 16,2005

Mr. Francisco Ortiz

4335 South Higuera

San Luis Obispo, CA 93401

Dear Francisco:

The Cal Poly Human Subjects Committee has reviewed your proposal, entitled "Factors contributing to immigrant Hispanic students' poor academic performance and the behaviors and beliefs of parents and students," and has found it to be in compliance with federal guidelines for the use of human subjects in research.

Please be aware that it is your responsibility as the person in charge of this research project to ensure that, with respect to human subjects, the work is carried out as described in the proposal and the rights of the subjects are fully protected.

We wish you success in your research efforts.

Sincerely,

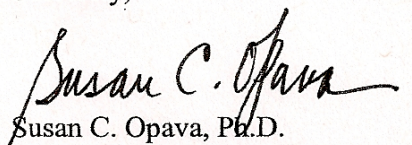

Susan C. Opava, PW.D.

Dean for Research and Graduate Programs

cc: Dr. Lisa Sweatt 